\title{
Phytoplankton in extreme environments: importance and consequences of habitat permanency
}

\author{
Judit Padisák (1) - Luigi Naselli-Flores $\mathbb{1}$
}

Received: 30 March 2020/Revised: 28 June 2020/ Accepted: 8 July 2020/Published online: 23 July 2020

(C) The Author(s) 2020

\begin{abstract}
There is hardly any sunshine exposed surface on this Earth, be it water or terrain, which would not support some biota. Still, many habitats offer harsh conditions requiring specialized physiological adaptations to survive. These environments are referred to as extremes; often inhabited by extremophilic organisms. In this review, characteristic species and assemblage properties of phytoplankton inhabiting extreme environments (especially lakes and pools where planktic life is potentially possible and independently of their origin) in terms of alkalinity, acidity, DOC, salinity, temperature, light and mixing regime will be outlined. Lakes characterized by more than a single extreme are common (e.g. saline + alkaline; acidic + high $\mathrm{DOC}+$ high metal content + low light). At the edge of extremes (e.g. pH
\end{abstract}

Guest editors: Judit Padisák J. Alex Elliott Martin T. Dokulil \& Luigi Naselli-Flores / New old and evergreen frontiers in freshwater phytoplankton ecology: the legacy of Colin S. Reynolds

\section{J. Padisák ( $\square)$}

Department of Limnology, Institute of Environmental Science, University of Pannonia, Egyetem u. 10, 8200 Veszprém, Hungary

e-mail: padisak@almos.uni-pannon.hu

L. Naselli-Flores

Department of Biological, Chemical and Pharmaceutical Sciences and Technologies (STEBICEF), University of Palermo, Via Archirafi, 28, 90123 Palermo, Italy

e-mail: luigi.naselli@unipa.it of 1; salinity over $\sim 100-150 \mathrm{~g}^{-1}$ ) single species with appropriate physiological adaptation are selected and the phytoplankton is often dominated by a single species (monodominant) setting compositional diversity to zero. Under less extreme conditions permanent equilibria may persist; in many cases over several years in contrast to ,average" lakes where equilibria are rare and ephemeral. Food webs depending on „extreme phytoplankton” are often atypical for example because the microbial loop is of prior importance or because birds are top predators.

Keywords Salinity $\cdot$ Acidity $\cdot$ DOC $\cdot$ Light . Phytoplankton $\cdot$ Food webs $\cdot$ Diversity $\cdot$ Ecological equilibrium

\section{Introduction}

There is hardly any sunshine exposed surface on this Earth, be it water or terrain, which would not support some biota. Still, many habitats offer harsh conditions needing specialized physiological adaptations to survive. These environments are referred to as extremes.

The adjective „extreme" has been increasingly used when analyzing phytoplankton patterns. Most of these cases concern events related to climate or meteorology (Havens et al., 2016; Crisci et al., 2017; Kasprzak et al., 2017) like extreme hydrologial 
periods (Devercelli, 2010; Mihaljević et al., 2010; Bortolini et al., 2016), extreme inflow (Leigh et al., 2015), extreme precipitation (Weyhenmeyer et al., 2004; Znachor et al., 2008; Stockwell et al., 2020 and literature therein) or extreme drought (Crossetti et al., 2019). These events are often related to the frequency increase of extreme events as a consequence of climate change. From an ecological point of view, they can be regarded as disturbance events fulfilling the definition provided by Reynolds et al. (1993): “disturbances are primarily non-biotic, stochastic events that result in distinct and abrupt changes in the composition and which interfere with internally-driven progress towards self-organization and ecological equilibrium; such events are understood to operate through the medium of (e.g.) weather and at the frequency scale of algal generation times". In this review disturbance events are not considered as extremes since adaptation is possible at community level. In above-cited papers, abrupt changes in composition of phytoplankton are reported but without dramatic change in species number or floral composition, though such extreme events may increase invasion sensitivity of phytoplankton assemblages (e.g. Padisák et al., 2010, 2016; Crossetti et al., 2019; Selmeczy et al., 2019).

In this review, dedicated to Colin S. Reynolds' (1942-2018) excellence, extreme conditions will be understood as it is in the classical niche-theory: one or more of the limnologically relevant variables show persistently values at the edges of a niche axis or of some niche axes. As such, alkalinity, acidity, DOC, salinity, temperature, light and mixing regime will be considered.

Species inhabiting extreme environments are called extremophiles from the Latin "extremus" (being on the outside) and "phila" (beloved) (Rotschild \& Mancinelli, 2001). They are often referred to as "simple organisms"- though they are not at all simple. Physiological adaptation to extreme conditions supposes relevant biochemical mechanisms like specialized proton pumps under acidic or hypersaline conditions (Weiss \& Pick, 1996; Gross, 2000), specialized photosynthetic apparatus in either extremely shaded or extreme light-exposed environments (Neale \& Priscu, 1995) or accumulation of certain compounds like carotenoids or fatty acids. For these reasons, extremophiles are favored by biochemical and biotechnological research (e.g. Hosseini Tafreshi, 2009). Evolution of adaptation to extreme environments are also not reviewed here though they are quite interesting and involve a number of mechanisms. For example, Schönknecht et al. (2013) demonstrated that Galdieria sulphuraria (Galdieri) Merola, a non-planktonic rhodophyte growing on hot, acidic and heavy metal rich habitats took up a number of genes by lateral gene transfer from archaea.

There are other terms used for species surviving in harsh environments. They are referred to as "enigmatic microorganisms" as a collective term for biota that "live now where no life might seem possible" (Seckbach, 2013). This definition nicely allows for the deduction that in times when they evolved the conditions what we qualify recently as extreme might have been just normal.

Another, recently often used term addresses "stress tolerant" species. Both Grime (2001) and Reynolds (1997) define "stress-tolerance" as mineral nutrients stress, but of course there is the possibility to be tolerant to other kinds of stress. Nevertheless, noone defines the intensity of stress above or below which the stress itself occur-with good reasons. Threshold values like hyposaline, mesosaline, hypersaline (e.g. Pallares et al., 2015) exist but they describe the habitat and not their biota. In general, there is quite a confusion in the recent literature on terms ,disturbance”, „stress”, „stressor”; a number of definitions are offered in Borics et al. (2013).

From an evolutionary point of view, fast growing microorganisms, and among them phytoplankton species, are favored test organisms to study adaptation mechanisms to extreme conditions being the most important question whether it occurs via pre- or postselection. Experimental results with Chlorella chlorelloides (Naumann) C. Bock, L. Krienitz \& T. Pröschold and Microcystis aeruginosa (Kützing) Kützing, both isolated from non-extreme waters, justified rapid genetic adaptation to culture media obtained from geothermal and ice-covered environments as consequence of single mutations at one locus (Costas et al., 2008). Single, rare, spontaneous mutations explained presence of "mesophilic species” in extremely contaminated (high levels of uranium, severe acidity and elevated conductivity) ponds receiving mining effluents (García-Balboa et al., 2013). Low-Decarie et al. (2016) isolated microorganisms, among them algae (identified based on OTU sequences: Chlorella sp., Ch. sorokiniana Shihira \& R.W.Krauss, Ch. variabilis Shihira \& R.W.Krauss, Coccomyxa sp., Pavlova sp.) 
from a common freshwater lakes and subjected them in reciprocal experiments to extreme $\mathrm{pH}$ and salinity. They found that there are many species in "common lakes" able to thrive or even grow under extreme conditions without any genetic selection. These results underpin the importance of biodiversity and role of sporadic species (Padisák, 1992; Padisák et al., 2010) in any kind of assemblages emerging when environmental conditions approach some kind of extremes. Species adaptation and community adaptation needs different "tools" and this directly drives us to Colin Reynolds's inheritance.

Colin Reyolds's approach to phytoplankton ecology was holistic with focus on selection of phytoplankton assemblages according to habitat properties. In line with this, biochemical details of adaptation to extreme environments are beyound the scope of this review, and we will rather be focussed on organization and compositional characteristics of their phytoplankton assemblages.

\section{pH, dissolved organic carbon}

From the point of view of phytoplankton, the $\mathrm{pH}$ gradient represents the degree of accessibility to inorganic carbon. It is determined by the $\mathrm{CO}_{2}{ }^{-}$ $\mathrm{HCO}_{3}{ }^{-}-\mathrm{CO}_{3}{ }^{2-}$ buffer system along the $1-14 \mathrm{pH}$ scale where $\mathrm{CO}_{2}$ is exclusive up to approx. 4 and $\mathrm{CO}_{3}{ }^{2-}$ above approx. 11.3. Between these thresholds $\mathrm{HCO}_{3}{ }^{-}$is present with a peak at $\mathrm{pH}$ approx. 8.3 where it maximizes its concentration (almost exclusive). In the $\mathrm{pH}$ range $4-8.3 \mathrm{CO}_{2}-\mathrm{HCO}_{3}{ }^{-}$co-exist.

All phytoplankton species carry on $\mathrm{C} 3$ type of photosynthesis being the Rubisco the key enzyme of intracellular carbon transport and carboxylation. However, Rubisco can deal only with $\mathrm{CO}_{2}$ and not with the $\mathrm{HCO}_{3}{ }^{-}$. Phytoplankton species are able to utilize $\mathrm{HCO}_{3}{ }^{-}$if they have carbon-concentrating mechanisms (CCMs) where carbonic anhydrase has a central role. This enzyme catalyzes the following reaction: $2 \mathrm{HCO}_{3}{ }^{-} \rightarrow \mathrm{CO}_{2}+\mathrm{CO}_{3}{ }^{2-}+\mathrm{H}_{2} \mathrm{O}$. The $\mathrm{CO}_{2}$ generated by this reaction can be used for carbon fixation, whereas the $\mathrm{CO}_{3}{ }^{2-}$ is released to the aquatic environment where it precipitates as $\mathrm{CaCO}_{3}$ when calcium is in sufficient supply. The available evidence suggests that the algae lacking CCMs are some terrestrial green microalgae, some freshwater red macroalgae and all of the freshwater chrysophytes and synurophytes examined (Raven et al., 2005). This explains why planktic chrysophytes and synurophytes do occur only at acidic or circumneutral $\mathrm{pH}$, however, a field observation suggests that there might be some species with effective CCMs (Reynolds et al., 1993).

Unlike $\mathrm{CO}_{2}$ and $\mathrm{HCO}_{3}{ }^{-}, \mathrm{CO}_{3}{ }^{2-}$ cannot be used as inorganic carbon source. For this reason, phytoplankton photosynthesis cannot be performed in pelagic environments having a $\mathrm{pH}>11.3$. There are, however, numerous lakes with highly alkaline $\mathrm{pH}$, among them the world's most productive lakes (Cózar et al., 2012; see details in chapter Salinity). Therefore, highly alkaline conditions do not limit primary production and standing crop bearing in mind that intensive photosynthesis in itself increases $\mathrm{pH}$. An example of stably alkaline ( $\mathrm{pH} 9.7-10.5)$ but nonsaline (conductivity: $532-2480 \mu \mathrm{S} \mathrm{cm}^{-1}$ ) lakes is Santa Olalla, Spain. Its relatively species-rich phytoplankton was highly dominated by Anathece clathrata (West \& G. S. West) Komárek, Kastovsky \& Jezberová (Lopez-Archilla et al., 2004). However, most of the highly alkaline lakes are not only alkaline but also saline, therefore, the effects of alkalinity and salinity cannot be separated. These lakes, as extremes, will be dealt with in the chapter "Salinity". An option would be to search for lakes receiving highly alkaline industrial wastewater. Though several studies can be found in the literature (e.g. Holopainen et al., 2008), the alkaline compound is not the only component of the waste: salts and/or heavy metals are also present in high concentration.

Experiments at highly alkaline $\mathrm{pH}(>10)$ were aimed at maintaining high growth rates for biofuel production along with lowering the supply costs of the $\mathrm{CO}_{2}$ by enhancing input of $\mathrm{CO}_{2}$ from the atmosphere at high rates. Both indoor and outdoor studies with Chlorella sorokiniana Shihira \& R. W. Krauss str. SLA-04 showed biomass and lipid productivities that were comparable to those reported for other microalgae cultivated in near-neutral $\mathrm{pH}$ media $(\mathrm{pH} 7-8.5)$ under similar conditions (Vadlamani et al., 2017). In another study Desmodesmus sp. EJ 9-2 grew in a $\mathrm{pH}$ range of 3-12 (Ji et al., 2015). These results indicate that extremely high $\mathrm{pH}$ does not decrease growth rates substantially but in lack of experiences in natural environments biodiversity issues cannot be discussed. For the above reasons, only the acidic edge of the $\mathrm{pH}$ gradient will be reviewed here in detail. 
A number of reasons may lead to acidic conditions. Slightly acidic lakes occur in high numbers in the boreal regions due to humic material ingress from the adjacent wetlands (Lepistö \& Rosenström, 1998), and some of them were further acidified by acid rains (Kenttämies, 1994). Inflow from a volcanic area into Andean Lake Caviahue, Argentina (Pedrozo et al., 2001) is the origin of its acidity and a number of acidic ponds and ditches occur in other volcanic areas. Abandoned surface coal mining places host a number of acidic waters of different size and morphology (Nixdorf et al., 1998). Sporadic events like ingress of acidic melting water may also result in very low $\mathrm{pH}$ (Yan \& Stokes, 1978). Whatever is the reason of low $\mathrm{pH}, \mathrm{CO}_{2}$ is the primary inorganic source of carbon. If primary production is relatively high, atmospheric $\mathrm{CO}_{2}$ dissolution cannot compensate consumption, which may lead to carbon limitation even at relatively high $\mathrm{N}$ and P levels (Beamud et al., 2010). N and P addition in an experimental system failed to trigger significant phytoplankton response at low $\mathrm{pH}$ in contrast to higher pH levels (Perez et al., 1994). This implies that traditional trophic classification is not readily applicable for these lakes (Nixdorf et al., 1998). Acidic lakes are often classified as dystrophic (i.e. without a definable trophic state; Górniak, 2016). A largely common feature of low $\mathrm{pH}$ lakes is coloration, but of several different reasons. In boreal lakes humic materials cause the brownish color (Lepistö \& Rosenström, 1998) and in acidic mining lakes the reddish to brownish color is due to dissolved iron-hydroxides (Kamjunke et al., 2004). Coloration of these lakes enhances light attenuation independently from algal biomass and also modifies the spectral composition of incident light (short wavelengths attenuating fast) but high inorganic turbidity is rare. With appropriate lake morphology this may allow for development of deep chlorophyll maximum as exemplified on Lepocinclis by Weithoff et al. (2010) in Lake Langau, Austria or for performing diurnal vertical migration like by Ochromonas in Grünewalder See, Germany (Beulker et al., 2003). Moreover, in this kind of lakes, especially when phosphorus availability is reduced, picoplanktic species can show high biomass and productivity (e.g. Jasser, 1997; Drakare et al., 2003).

Commonly, lakes having a $\mathrm{pH}$ less than 5.5 are considered acidic (Lepistö \& Rosenström, 1998), which is supported by a number of studies. Primary production and biomass of phytoplankton are either decreasing or are non-responsive (Findlay, 2003) to $\mathrm{pH}$ drop in the range of 4-7 (Kwiatkowski \& Roff, 1976) unlike phytoplankton diversity, which appeared to be the most powerful indicator, especially at $\mathrm{pH}$ lower than 5.5 as was shown in both Canadian (Kwiatkowski \& Roff, 1976; Yan \& Stokes, 1978) and Swedish (Hornström, 2002) lakes.

In "average" lakes with quasi-neutral $\mathrm{pH}$ phytoplankton assemblages are diverse and composed of many (over 100) species belonging to different taxonomic and functional groups. Some widely distributed species [e.g. Limnococcus (Chroococcus) limneticus (Lemmermann) Komárková, Jezberová, O. Komárek \& Zapomelová, Asterionella formosa Hassall, Cyclotella meneghiniana Kützing] have not been recorded in acidic lakes (Blouin, 1989). At moderately acidic $\mathrm{pH}$, dinoflagellates often gain dominance. Various species were found under such conditions like Peridinium volzii Lemmermann ( $\mathrm{pH}$ 6.5; Hargraves \& Viquez, 1981); Parvodinium inconspicuum (Lemmermann) Carty ( $\mathrm{pH}$ 4.5-6.3; Perez et al., 1994); Peridiniopsis quadridens (F.Stein) Bourrelly, Peridinium limbatum (Stokes) Lemmermann; Gymnodinium fuscum (Ehrenberg) F.Stein (pH 5.1; Graham et al., 2004); Peridinium umbonatum F. Stein (pH 3.6-4.3; Nixdorf et al., 1998).

Further decrease of $\mathrm{pH}$ commonly shifts dominance towards small chlorophytes and chrysophytes. In abandoned, open-cast brown coal mines over 200 small lakes offered a gradient of low $\mathrm{pH}(2-4)$ to study phytoplankton response to such conditions (Kamjunke et al., 2004). Species surviving in these acidic environments include Chlamydomonas, Ochromonas, Chromulina, Lepocinclis, Euglena and Nanochlorum in German mining lakes (Nixdorf et al., 1998, Lessmann et al., 2010) or Keratococcus, Chloridella, Chlamydominas, Viridella and Euglena in Lake Caviahue, Patagonia (Pedrozo et al., 2001). In Lake Rotowhero, New Zealand, a geothermal lake with permanent mixing, a small chlorelloid green alga is the only phytoplankton species at pH 3.5 (Brookes et al., 2013). A recently described species, Autumnella lusatica Ulrich \& Röske (Chlorophyta, Trebouxiophyceae), though grows well in neutral medium, tolerates $\mathrm{pH}$ down to 3 at low $\mathrm{P}$ and inorganic carbon concentrations and can build up substantial biomass thus being a successful competitor of the mixotrophic species typical for such lakes. In stratifying lakes its 
entrainment in the epilimnion is assisted by its elongated shape and presence of oil droplets in the cytoplasm (Ulrich \& Röske, 2018).

These species are selected by their ecophysiological features for tolerating such environments but have some common morphometric features: they are small (except euglenophytes) with cell volumes below $200 \mu^{3}$ and are either quasi-spherical with a length/ width ratio between 1 and 2 or elonated like Autumnella and Keratococcus.

In lakes with $\mathrm{pH} \sim 2$, phytoplankton assemblage is further reduced to only some mixotrophic species, like Chlamydomonas and Ochromonas since under such conditions inorganic carbon limitation, combined with high level of proton concentration stress, becomes severe (Tittel et al., 2005).

Humic lakes can be found in high numbers especially across the north temperate region. Though high Pt/Co color (Platinum-Cobalt scale or AphaHazen scale is a color scale originally intended to standardize the colour of waste water and later expanded to other applications as the measure of the humic content) is often associated with acidic $\mathrm{pH}$, latter is not an obligate characteristics of humic lakes since they may exhibit very alkaline $\mathrm{pH}$ combined with relatively high salinity (e.g. some soda pans in the Carpathian basin-Boros et al., 2014; reedless inner lakes of Lake Fertö-Padisák, 1993).

Though high $\mathrm{Pt} / \mathrm{Co}$ colour profoundly influences light attenuation, both in terms of quantity and quality (Balogh et al. 2000) it appears to select rather for traits than to species. According to Lepistö \& Rosenström (1998) the prominent functional groups (sensu Reynolds et al., 2002) comprise motile taxa (coda Y, X3, $\mathbf{U}, \mathbf{Q}$ ) and weakly silicified diatoms (codon $\mathbf{A}$, Urosolenia). Some "iconic" species seem to be restricted to humic lakes. As an example, Gonyostomum semen (Ehrenberg) Diesing (codon Q) can form nuisance blooms (and swimmer's hitch) when the $\mathrm{pH}$ is slightly acidic, concentration of DOC/humic materials and nutrients are high and light gradient is sharp (Lepistö et al., 1994; Korneva, 2001; Rengefors et al., 2012). The species is spreading in northern Europe to many lakes with higher $\mathrm{pH}$ as was quite early noted by Cronberg et al. (1988). Another species of this genus, Gonyostomum latum Ivanov, occurs at lower latitudes, e.g. in oxbow lakes of the Carpathian basin (Schmidt et al., 1990). These lakes are not acidic ( $\mathrm{pH}$ $\sim$ 7.3-8.4), but their DOC content is high. It is easy to overlook Gonyostomum spp. since they disintegrate in Lugol-fixed samples. However, it seems that the DOC content rather than the $\mathrm{pH}$ of the habitat is of prior importance.

Another species with apparent need for DOC, especially organically rich sediments, in mainly small lakes across the cold-temperate climate region is Gloeotrichia echinulata P. G. Richter (e.g. Jacobsen, 1994). It occurs in lakes of different trophic state (Carey et al., 2008) and has both benthic and planktic growth phases (Istvánovics et al., 1993).

\section{Salinity}

Salinity (salt content expressed in $\mathrm{g} \mathrm{l}^{-1}$ ) is often measured as electric conductivity $\left(\mathrm{mS} \mathrm{cm}^{-1}\right)$ though precise relationship cannot be established since small, charged, organic molecules contribute to conductivity but not to salinity. However, close correlations $\left(r^{2}>0,9\right)$ between these variables was demonstrated e.g. by Williams (1986) using data from 109 Australian lakes in the range of $5-100 \mathrm{mS} \mathrm{cm}^{-1}$ and Zinabu et al. (2002) in Ethiopian lakes and rivers (salt content: $0.08-33.7 \mathrm{~g} \mathrm{l}^{-1}$ ).

Saline lakes occur all over the world. Athalassohaline (not deriving from the sea) lakes are either salt lakes or soda lakes. Dominant ions in salt lakes are $\mathrm{Na}^{+}$and $\mathrm{Cl}^{-}$(e.g. Great Salt Lake, Utah; pH 7-8) or $\mathrm{Na}^{+}, \mathrm{Mg}^{2+}$, and $\mathrm{Cl}^{-}$(e.g. Dead Sea, Israel; pH 6-7). Soda lakes (e.g. Lake Magadi, Kenya; pH 10-12) commonly have $\mathrm{Na}^{+}, \mathrm{CO}_{3}{ }^{2-}, \mathrm{HCO}_{3}{ }^{-}$and $\mathrm{Cl}^{-}$as main ions (Grant et al., 1998). Some lakes have other types of ionic composition as a consequence of receiving groundwater from deep aquifers (Mádl-Szőnyi \& Tóth, 2009). Heliothermic lakes (Ionescu et al., 1998) and permanently frozen lakes at high latitudes are often characterized by hypersaline conditions (Stewart \& Platford, 1986). Salinity of continental saline lakes may well exceed that of the seawater.

Dead Sea (Israel) with its 270-340 $\mathrm{g} \mathrm{l}^{-1}$ surface salt content is a typical example of hypersaline, $\mathrm{Na}^{+}$, $\mathrm{Mg}^{2+}$, and $\mathrm{Cl}^{-}$type lakes. In those periods when fresh waters from the Jordan river dilute the surface waters by at least $10 \%$ (Oren, 1999), Dunaliella sp. is the only representative of phytoplankton, similarly to Mediterranean saltpans (Asencio, 2013). Taxonomy of the genus Dunaliella has been still confused and molecular DNA sequence-based approaches have done little 
to solve the problems of the classical morphologybased taxonomy being $D$. salina (Dunal) Teodoresco and D. parva W.Lerche, the most frequently reported species, both occurring at a wide salt range (9-200 $\mathrm{g} \mathrm{l}^{-1}$; Oren, 2014). According to ecophysiological experiments, their growth optima is lower than the salinity range of the environments they occur: $\sim 60-90 \mathrm{~g} \mathrm{l}^{-1}$ for D. viridis Teodoresco and $\sim 100-150 \mathrm{~g} \mathrm{l}^{-1}$ for D. salina (Borowitzka, 1981). Survival of Dunaliella at salinities exceeding its tolerance limits, caused either by drastic dilution of the water or drying-up, is assisted by formation of asexual thick-walled non-motile cysts with bumpy surfaces (aplanospores) or palmelloid stages encased in a gelatinous mucilage (Oren, 2014), a multifunctional adaptation tool of phytoplankton (Reynolds, 2007), that allows for survival in the dry sediments. Observations by remote sensing recorded starts of blooms originating from shallow areas (Oren \& BenYosef, 1997) and formation of resting stages was observed during the decline of blooms (Oren et al., 1995). Dunaliella is a good example for understanding that evolutionary/biochemical adaptation, survival and dispersion strategy, and habitat heterogeneity are all to be regarded when we try to understand the success of a particular species (Naselli-Flores \& Padisák, 2016; Padisák et al., 2016).

The Great Salt Lake, Utah, is a typical example of salt lakes with similar ionic dominance as that of the Dead Sea. Like in other saline lakes, salinity varies in a wide range (10-160 $\mathrm{g}^{-1}$ ) depending on precipitation patterns. Typical phytoplankton is composed by chlorophytes (Dunaliella viridis, D. salina, Carteria sp., Oocystis sp., Treubaria triappendiculata C. Bernard, Sphaerellopsis sp., Spermatozopsis sp.), occasionally dinophytes (Glenodinium sp.) with a number of diatoms of which only Cyclotella sp. and Chaetoceros sp. are planktic. Cyanobacteria include Nodularia sp., Microcoleus sp. Pseudanabaena sp. and Spirulina sp. (Wurtsbaugh \& Marcarelli, 2004). Phytoplankton composition is controlled both by salinity and nutrients. According to laboratory bioassays, the approx. $70 \mathrm{~g} \mathrm{l}^{-1}$ salt concentration represents a critical limit. Above this threshold, Dunaliella is dominating and its standing crop is controlled by the availability of nitrogen. When salinities drop below $70 \mathrm{~g} \mathrm{l}^{-1}, \mathrm{~N}_{2}$-fixing cyanobacteria (especially benthic Nodularia spumigena Mertens ex Bornet \& Flahault) appear and the overall production becomes P-limited (Marcarelli et al., 2006).

Similar, though less "famous" lakes occur all over the world, such as Urmia Lake, Iran (Esmaeili Dahesht et al. 2010) with overwhelming Dunaliella dominance and occasional presence of diatoms (Nitzschia, Navicula, Synedra). In the hypersaline lakes formed in abandoned salt mines in the Transylvanian Basin (Romania) some dinoflagellates and small cryptophytes were present typically below $60 \mathrm{~g} \mathrm{l}^{-1}$ salt content. Eukaryotic picoplankton dominated the phytoplankton in the $61-170 \mathrm{~g}^{-1}$ salinity range and above this value Dunaliella became largely monodominant (Somogyi et al., 2014).

Saline-alkaline lakes (often referred to as soda lakes) are characterized by high $\mathrm{pH}$ (over 9) and are rich in carbonate forms with additional $\mathrm{Cl}^{-}$and $\mathrm{SO}_{4}{ }^{2-}$. Typical examples are the African lakes famous about their dense flamingo populations. Salinity in these lakes may reach extremely high values towards the end of the drying out periods but rarely exceeds $70 \mathrm{~g} \mathrm{l}^{-1}$; pH often exceeds 10. These lakes are characterized by the almost monodominance of Limnospira fusiformis (Voronichin) Nowicka-Krawczyk, Mühlsteinová \& Hauer (syn. Arthrospira fusiformis (Voronichin) Komárek \& J.W.G. Lund [in early publications Spirulina, or S. platensis (Gomont) Geitler]. Limnospira with its large sizes serves as food for the Lesser Flamingo (Phoeniconaias minor E. Geoffroy Saint-Hilaire, 1798). It is one of the most productive phytoplankton species being able to double its biomass every 11-20 h (Vonshak et al., 1996) under high temperature and light conditions (Kebede \& Ahlgren, 1996) thus providing a continuous food supply for the dense Lesser Flamingo populations. In Kebede's (1997) turbidostat experiments, in a carbonate-dominated medium and salinity ranging between 13 and $88 \mathrm{~g} \mathrm{l}^{-1}$, this cyanobacterium showed the highest growth rate at the lowest salinities.

Collapse of Limnospira populations with irregular (often multi-annual) periodicity was observed in many African lakes and was explained by various reasons like changes in salinity, nutrient concentrations, water level; outcompeting by other species (filamentous cyanobacteria, coccoid or flagellated algae), attacks by cyanophages (Peduzzi et al., 2014) or autolysis (Vareschi, 1982; Melack, 1988; Oduor \& Schagerl, 2007; Schagerl \& Oduor, 2008). Krienitz and Kotut (2010) described a similar fluctuation in 
phytoplankton composition in three Kenyan soda lakes where Limnospira was outcompeted by an unidentified Anabaenopsis sp. and Picocystis salinarum $\mathrm{R}$. A. Lewin, both being previously subdominant. $P$. salinarum is a particularly important species when regarding phytoplankton in saline environments. The species was described only in 2000 (Lewin et al., 2000) from a saline pond at the San Francisco Salt Works and later was recorded from a number of saline environments across almost all continents (Inner Mongolia-Hollibaugh et al., 2001; Mono lake USA Roesler et al., 2002; Fanjing et al. 2009; North Africa-Rihab et al., 2017; Peru-Tarazona Delgado et al., 2017; India-Krienitz, 2018; Mayotte Island, Indian Ocean-Cellamare et al., 2018; Bernard et al., 2019).

$P$. salinarum has strikingly different morphological and ecophysiological properties than Limnospira platensis: it is shade tolerant, much less productive, tolerates high salinities, is of picoplanktic size, therefore, unsuitable to be grazed by flamingos (Pálmai et al., 2020) and according to some observations is able to tolerate cold temperatures (Fanjing et al., 2009). The species appeared to be sensitive to salt composition of the medium: growth rates were significantly higher in a carbonate dominated medium as compared to a chloride dominated one (Pálmai et al., 2020). Though described from marine environments (Fawley et al., 2015), Eustigmatophytes of the genera Nannochloropsis and Microchloropsis may play a role in extreme saline inland waters as their presence was supported in e.g. Namibian lakes (Krienitz, 2018).

Occassionally and especially after Limnospira blooms diatoms gain dominance in East African saline lakes (Hecky \& Kilham, 1973): Cyclotella meneghiniana is common in less concentrated lakes and as salinity increases Craticula (Navicula) elkab (O.Müller ex O.Müller) Lange-Bertalot, Kusber \& Cocquyt and Thalassiosira (Coscinodiscus) rudolfii (Bachmann) Hasle and finally Nitzschia frustulum (Kützing) Grunow are typical. Many diatom species occur, or even reaches bloom amounts such as Anomoeoneis sphaerophora Pfitzer, in saline habitats of different origin like soda lakes, marine mudflats, salt evaporation ponds or salt pans and some of them are of importance for the whole food-web (Krienitz et al., 2016).
A number of shallow hypo- or mesohaline lakes can be found at higher latitudes; many of them are astatic or semiastatic (with annual or interannual frequency they dry out completely or do not dry out but show high water level fluctuation depending on precipitation patterns). Their salinity may reach a maximum of $60 \mathrm{~g} \mathrm{l}^{-1}$. Their "higher than freshwater" salinity is combined with $\mathrm{pH}$ above 9 , high inorganic turbidity and high daily temperature variation. Additionally, type-specific annual hydrological regime complicates understanding selective forces driving phytoplankton changes (Lengyel et al., 2019). Typical examples are soda pans in the Carpathian basin (see description in Boros et al., 2014). In these cases it is difficult to decide that salinity, alkalinity, turbidity or daily temperature variation is the most decisive component of their extremity. Some features of their phytoplankton will be mentioned in the chapter "Temperature and light".

There are some species, which indicate salinity increase in hyposaline lakes. One of them is Chaetoceros muellerii Lemmermann appearing in lakes when conductivity exceeds about $3000 \mu \mathrm{S} \mathrm{cm}^{-1}$ (Calvo et al., 1993; Padisák \& Dokulil, 1994; Barone et al., 2010). One of the main triggers of the increasing incidence of Prymnesium parvum N. Carter nuisance blooms is salinity increase (Roelke et al., 2016).

\section{Temperature and light}

Due to physicochemical properties of water, lakes have a well balanced, slowly changing temperature climate with variation between 0 and about $40^{\circ} \mathrm{C}$ in contrast to terrestrial habitats with much faster and wider variation of temperatures. According to ecophysiological studies using combined light-temperature gradients, low temperatures are allied with increased shade tolerance with no known exception. However, cold adapted species reach their maximum photosynthetic activity at temperatures no higher than $20^{\circ} \mathrm{C}$ and above this threshold they become lightinhibited while species adapted to high temperature do not show light inhibition at all due to their effective mechanisms to avoid photo-oxidation, as shown by different models for cases with yes/no photo inhibition (Webb et al., 1974; Platt et al., 1980).

For the above reasons, phytoplankton is not the best group of organisms to explore limits of algal life in 
environments characterized by extreme temperatures. Snow or ice surfaces (low temperature + high light) allow for development of largely non-phytoplanktic algal assemblages (Säwström et al., 2002), and hotsprings (Castenholz, 1969) also support adapted algal species.

The light-photosynthesis ecophysiological experiments are mostly aimed at exploring optimal growth conditions therefore the experiments are mostly run in the temperature range $5-35^{\circ} \mathrm{C}$ with no or at least little attention to find upper or lower tolerance limits, which would be essential for understanding survival or even success of some species within suboptimal temperature/light conditions. An interesting example is Aphanizomenon flosaquae Ralfs ex Bornet et Flahault, a common late summer species in eutrophic lakes at higher latitudes. This species pertained net photosynthesis under extremely dark and cold $\left(2^{\circ} \mathrm{C}\right)$ conditions both in lab experiments and in Nature where it was observed to bloom under the ice cover (Üveges et al., 2012).

The poorly explored hydro-physical convectional movements under long-lasting lake ice (Bouffard et al., 2016, 2019; Pernica et al., 2017) act as floating aid for species adapted to grow under such conditions. A number of species, mostly diatoms, possess this ability like Aulacoseira spp. and Urosolenia longiseta (O. Zacharias) Edlund \& Stoermer in Lake Pääjärvi, Finland (Vehmaa \& Salonen, 2009); Uroglena sp., Stephanodiscus cf. parvus Stoermer \& Håkansson, Asterionella formosa and Aulacoseira spp. in Lake Vesijärvi, Finland (Salmi \& Salonen, 2016); Stephanocostis chantaica Genkal et Kuzmina in Lake Stechlin, Germany (Scheffler \& Padisák, 2000) and in Lake Tovel, Italy (Cellamare et al., 2016); Aulacoseira baicalensis (K. Meyer) Simonsen in Lake Baikal (Jewson et al., 2009).

In other permanently ice-covered lakes phytoplankton traits with good floating abilities are characteristic like flagellated species of chrysophytes, cryptophytes and chlorophytes or buoyant cyanobacteria (Vincent \& Vincent, 1982; see more details in Izaguirre et al., 2020).

Convection currents are of major importance in selection of phytoplankton assemblages in areas where day-night air temperature difference is high; typically in the tropical and subtropical regions and/or at high altitudes. Convectional currents generated at daily frequency result in a special mixig type: atelomixis
(Lewis, 1978; Barbosa \& Padisák, 2002), which is either complete (expands to the whole water column) or partial (restricted to the epilimnion). The regular daily mixing keep non-motile species, first of all small-celled desmids and in some cases small diatoms, in suspension thus making possible to avoid ultimate sedimentation to the dark layers. "Atelomictic" assemblages taxonomically are not monospecific as a number of species contribute but dominance of the $\mathbf{N}_{\mathbf{A}}$ (Borics et al., 2005; Padisák et al., 2009) functional group is overwhelming. Case studies are described from all over world with relevant climate, like Lake Zirahuén, Mexico (Tavera \& Martínez-Almeida, 2005), Dom Helvécio and Carioca lakes, Brazil (Souza et al., 2008; Barbosa et al., 2011, 2013); Lake Cuicocha, Ecuador (Gunkel \& Beulker 2009); Feitsui Reservoir, Taiwan (Wu \& Kow, 2010); Lake Hayq and Lake Wonchi, Ethiopia (Fetahi et al. 2010; Degefu \& Schagerl, 2015); Lake Kivu, East Africa (Rugema et al., 2019).

Geothermal lakes would be ideal for finding thermoadapted phytoplankton species. However, their surface temperature rarely exceeds that of the ,normally high" (up to $45^{\circ} \mathrm{C}$ ) and most of them are highly kinetic habitats. Mixing regime, therefore, is probably a more important selective force than temperature alone. These lakes will be mentioned in the chapter ,Mixing regime and turbidity”.

There is another "extreme" that has to be considered: high UV radiation, which might be of relavance in high miuntain lakes' phatopkankton. There are a number of papers (not reviewed here) dealing with physiological aspects of this issue, but field observations are rare. In in situ mesocosm experiments no real difference was found btween UV exposed and protected enclosures (Halac et al., 1997). Experiments with and without natural UV-B radiation using samples from a high mountain lake species-specific sensitivities and tolerances were found (Cabrera et al., 1997): when the mesocosms were exposed to full sunshine Ankyra judayi (G. M. Smith) Fott reached highest density while in UV-shaded ones Staurosira construens Ehrenberg and Fragilaria crotonensis Kitton were dominant. However, pupulation changes depended on the longevity the experiments: different results were obtained in short-, medium- and longterm exposures. Interesting size dependence was found in natural phytoplankton from three arctic lakes (van Donk et al., 2001). Short wavelength radiation 
inhibited growth of small sized species (chlorophytes, diatoms, picocyanobacteria) and large sized, colonial or filamentous species like Planktothrix sp., Woronichinia sp, and Uroglena americana Calkins were apparently stimulated. The reason behind might be that the distance between the cell surface and the DNA is shorter in small than in big cells as absorbance of short wavelengh radiation by intracellulat "sunscreens" is a function of cell size (Gracia-Pichel, 1994). Observations on the Antarctic marine prymnesiophyte Phaeocystis pouchettii (Hariot) Lagerheim found that colonies contained significant amounts of the UV-absorbing micosporine than the free-swimming single cells of the same species (Marchant et al., 1991). These results allow the conclusion that inrceased UV radiation has a substantial impact on the community composition of phytoplanton (and because of size dependence on the entire food-web), but the species selection highly depends on the original species composition of the habitat.

\section{Mixing regime and turbidity}

Periodic mixing is a common event in most lakes. Generated by temperature gradients developing in the water masses, it is mediated either by wind (mono, diand polimictic lakes) or convective currents (amictic and atelomictic lakes). Phytoplankton is well adapted to these periodic changes, which, according to their frequency and extension act as master driver of selection of different traits (Reynolds et al., 2002). In shallow lakes, frequent mixing results in sediment resuspension and then its effect on phytoplankton depends on the depth of the lake and on the sedimentation velocity of the resuspended inorganic particles. If sedimentation is slow, Secchi transparency is reduced $(0.5-20 \mathrm{~cm})$ and the lake are almost always inorganically turbid. In other words, such lakes are shallow by their absolute depth but are optically even more shallow (euphotic depth is permanently smaller than water depth). Optical shallowness can either be caused by high algal density or high inorganic turbidity. Such lakes occur all over the world (see review by Boros et al., 2017 and literature therein) and in many cases low transparency is a combined consequence of high turbidy and hypertrophic conditions resulting in dominance of cyanobacteria. Examples are Lake Aktaş (Turkey) with dominant
Planktolyngbya contorta (Lemmermann) Anagnostidis \& Komárek (Özbay \& Kılınç, 2008) and Lake Baringo (Kenya) with Microcystis dominance (Schagerl \& Odour, 2003). These cases will not be discussed in detail since, as was nicely shown by Allende et al. (2009), inorganic and phytoplankton-caused turbidity result in very different algal assemblages. Optical properties alone are not sufficient for characterizing phytoplankton assemblages (Scheffer et al., 1993).

Most likely because of difficulties in counting „Utermöhl-phytoplankton” in inorganically turbid lakes, very few papers with species-specific data are published about their phytoplankton but some examples are available. Lake Fertő (Neusiedlersee) is a mesotrophic, macrophyte-free, inorganically turbid lake located in Europe, in the wind corridor between the Carpathian mountains and the Alps with average depth of $1.3 \mathrm{~m}$ and maximal Secchi transparency not exceeding $20 \mathrm{~cm}$ in ice-free periods. Phytoplankton is dominated by large sized diatoms: long chains of Staurosira construens Ehrenberg, Campylodiscus clypeus (Ehrenberg) Ehrenberg ex Kützing, Surirella peisonis Pantocsek (Padisák \& Dokulil, 1994). Similar cases are described from elsewhere with dominance of Aulacoseira spp. and Closterium aciculare T. West (Izaguirre et al., 2012) or Licmophora antartica G. W. F. Carlson (Unrein \& Vinocur, 1999).

In very shallow (less than $0.5 \mathrm{~m}$ ), highly turbid soda pans, diatoms are represented mostly by several small-sized, weakly silicified species belonging to the genus Nitzschia. As day-night temperature variation is high (Boros et al., 2017) in these lakes, atelomixis might help these species to be entrained enough for supporting growth (Lengyel et al., 2015, 2020).

As was evidenced by quatification of phytoplankton both with inverted- and epifluorescence microscopy in Lake Fertő, autotrophic picophytoplankton is the other main representative of phytoplankton (Padisák \& Dokulil, 1994) in shallow and optically even more shallow shallow $\left(z_{\mathrm{eu}}<z_{\text {mix }}\right)$, inorganically turbid lakes. Other studies reported on similar observations independently from geographic location (Unrein \& Vinocur, 1999; Allende et al., 2009; Pálffy et al. 2014; Somogyi et al., 2017).

As can be revealed from the available data, inorganically turbid shallow lakes allow for coexistence of less phytoplankton species than others with "average conditions". Species number per 
sample rarely exceeds 10, therefore compositional diversity is kept low because species number is low.

A small number of functional groups characterizes these lakes (MP meroplanktonic diatoms: Staurosira, Melosira, Campylodiscus, Surirella and/or large desmids belonging to codon $\mathbf{N}$, see Padisák et al., 2009) periodically resuspended by winds. These species spend most of their life-time settled to the aphotic soft sediments where they may avoid burial because of their large sizes and winds periodically resuspend them into the shallow euphotic zone (meroplankton dynamics; Padisák \& Dokulil, 1994). Photosynthesis of most diatoms saturates at low light intensities and plankonic desmids, in general, are among the most shade tolerant species within „green algae". Additionally, sediment surfaces are richer in nutrients than the water column which facilitates nutrient acquisition.

According to Padisák et al. (2009), small Nitzschia spp. abundant in very shallow lakes belong to codon C but the strategy they follow in this case is similar to that of $\mathbf{N}_{\mathbf{A}}$ members. Benefits are those descibed here for MP species with the difference that the driving force of resuspension is not the wind but the atelomixis. Picocyanobacteria (codon K) fit to these environmental conditions since they benefit from their small sizes or, if colony forming, because the organisms' density is very close to that of the water (Reynolds, 2007), and therefore, they sink slowly. Shade tolerance contributes to their success. Subdominant taxa in inorganically turbid lakes can mostly be allocated to coda $\mathbf{F}$ and/or $\mathbf{X 1}$. Codon $\mathbf{F}$ comprises species with well deceloped mucilage slowering sinking rates. A good example is Lake Fertő with almost permanent subdominance of Oocystis lacustris Chodat and occassional presence of such a rare species as Lobocystis dichotoma R. H. Thompson (Dokulil \& Padisák, 1994; Padisák \& Dokulil, 1994). For codon X1 small sizes and attenuated shape (Padisák et al., 2003; Naselli-Flores et al., 2020) ensures low settling velocity. Examples are from Lake Fertö (Monoraphidium contortum (Thuret) Komárková-Legnerová, $M$. pseudobraunii (J. H. Belcher \& Swale) Heynig; Dokulil \& Padisák, 1994; Padisák \& Dokulil, 1994), Lake Aktas, Turkey (M. contortum, M. irregulare (G.M.Smith) Komárková-Legnerová; Özbay \& Kılınç, 2008) and Argentinian pampa lakes ( $M$. contortum; Allende et al., 2009).
A completely different environmental scenario was described by Brookes et al. (2013) in Lake Rotowhero, New Zealand, a $14 \mathrm{~m}$ deep geothermal lake receiving some $10 \mathrm{~L} \mathrm{~s}^{-1}$ of hot water $\left(\sim 70^{\circ} \mathrm{C}\right)$, which results in a surface lake temperature of $35.7-37.7^{\circ} \mathrm{C}$ (diurnal range). The $\mathrm{pH}$ of the lake is 3.5 for geothermic reasons. The continuous circulation consequent on geothermal input and atmospheric instability negates any tendency of thermal stratification, entraining phytoplankton and dispersing them all over the lake water. The only phytoplankton species that could build up a persistent population under such circumstances is a small, spherical chlorelloid green alga (no genetic analysis has been conducted for precise identification).

Hévízi-tó (Hungary) is the largest (7.75 ha) and deepest $(26 \mathrm{~m})$ natural geothermal lake in Europe. Most of its physical and chemical properties vary in "average" ranges - surface temperature varies from $20^{\circ} \mathrm{C}$ (winter) to $32^{\circ} \mathrm{C}$ (summer); $\mathrm{pH} 6.9-8.0$; conductivity: $634-728 \mu \mathrm{S} \mathrm{cm}^{-1} ; \mathrm{Ca}^{2+}$ and $\mathrm{HCO}_{3}{ }^{-}$are the dominant ions (Vízkelety, 1981). From the point of view of phytoplankton, the only extreme is the retention time, which is estimated as 2-3 days. Such a short residence time does not allow stratification, and its time-scale corresponds to or less than the doubling time of natural phytoplankton. This means, that any planktonic population will be washed out before it could double, and therefore, the lake does not support the development of even a monospecific phytoplankton "assemblage". The only paper (Vízkelety, 1981) available on the algae of the lake reports on the presence of a rich algal flora with 78 species; most are attached to surfaces. Oscillatoria tenuis C. Agardh ex Gomont and Pseudanabaena papillaterminata (Kiselev) Kukk are named as dominants in the open water samples; none is planktic. Consequence is that at retention time below 3 days neither phytoplankton assemblage can develop nor a sufficiently adapted phytoplankton species can persist.

Hypolimnetic aeration installed in some lakes for avoiding inconvenient consequences of anaerobic conditions may generate similar mixing conditions as in Lake Rotowhero or in the Hévízi-tó, however, no general pattern arises. Not surprisingly, such a management favors non-buoyant diatoms or at least extends the longevity of the spring diatom bloom (Webb et al., 1997; Kozak et al., 2017). In another case three species of cyanobacteria [Limnothrix redekei (Goor) Meffert, Pseudanabaena limnetica 
(Lemmermann) Komárek and Aphanizomenon gracile Lemmermann] dominated in the phytoplankton.

\section{General discussion}

Inland waters offer very different habitats for phytoplankton growth: almost all, or probably all, of their ecologically relevant environmental parameters can reach more extreme values than observed in the sea, could it be salinity, acidity/alkalinity, DOC content, turbidity, mixing regime or trophic status.

Selection of assemblages under the ,given” environmental conditions is much more complex than could be explained by individual adaptation to a singular constrain, though, some of these constrains may be so strong that requires special biochemical and physiological adaptations. Probably the best example is Dunaliella salina in highly saline, or Ochromonas spp. + Chlamydomonas spp. in highy acidic waters.

A number of environmental variables were considered in this review. However, it is often difficult to substantiate phytoplankton response to the extremes of these variables since multiple stress is common. For example, in acidic mining lakes besides the low $\mathrm{pH}$, concentrations of sulphate, aluminum, iron and other heavy metals are several orders of magnitude higher than those typical in circum-neutral lakes and coloration might also be important (Weithoff et al., 2010). In other lakes, high humic material content with its consequences on light climate contributes to extremity set by acidity. At the other edge of the $\mathrm{pH}$ scale, highly alkaline lakes are often saline and, additionally, many are astatic requiring adaptation to survive desiccation periods (Incagnone et al., 2015). These constraints alone or in combination offer highly selective environments suitable only for a limited number of species with relevant morphological, physiological and biochemical adaptations. This determines an important feature of their phytoplankton: low species number and low compositional diversity (Fig. 1).

In the particular papers cited in this review two common features related to phytoplankton emerge: uncommon structure of food-webs and high frequency of equilibrium/steady state phytoplankton composition.
Food webs

Food-webs of extreme environments are often referred to as "simple". Indeed, food-webs are markedly different from those typical in "average" pelagic ecosystems but it does not mean they would be simple either because the microbial food-web is dominant and rather complex or because top predators are birds. Weithoff et al. (2010) found a nice example of indirect competition between Ochromonas and Chlamydomonas in acidic mining lakes: the osmo-mixotrophic Chlamydomonas competed with bacteria for dissolved organic carbon and the phago-mixotrophic Ochromonas grazed on bacteria. Other components of the food web consisted of two rotifers, and heliozoans represented the top predators at $\mathrm{pH}$ 2.6-2.9 (Bell et al., 2006). As shown by Wollmann et al. (2000) in similar environments, as $\mathrm{pH}$ raises to 3.4-3.8, the complexity of the food-web increases and the pelagic-benthic coupling gains increasing importance.

Food-webs in saline lakes are at first sight simple. In salt lakes, algae are grazed by brine shrimp (Artemia species complex), which then are finally consumed by a variety of birds, e.g. the eared grebes (Podiceps nigricollis Brehm, 1831; Belovsky et al., 2011). In the African saline-alkaline lakes the Limnospira $\rightarrow$ Lesser Flamingo is the dominant trophic pathway. After periodic collapses of the Limnospira population flamingoes graze on other algae if they reach the minimum grazeable size (about $20 \mu \mathrm{m}$ ) otherwise, as is the case when Picocystis gains dominance, they abandon the lake with all its touristic and economic consequences. Just a note: this is an interesting case when grazeability is set by the smaller and not by the highest threshold value of the main predators. However, after collapses of the Limnospira blooms otherwise benthic diatoms can be considered as functionally planktonic (Hecky \& Kilham, 1973) though not all of them are sufficiently big for reaching the lower grazeable limit for the lesser flamingoes. An interesting example is the meroplanktonic Opephora in saline waters of Namibia, which falls into the lower size range of edibility by the top predator. Many small cells, not held by the filter lamellae, form the inoculum for a sizeable Opephora population in salt evaporation ponds (Krienitz et al., 2016).

In many other saline habitats Greater Flamingos (Phoenicopterus ruber Linnaeus, 1758) are filterfeeding on the brine shrimp Artemia salina, which is 


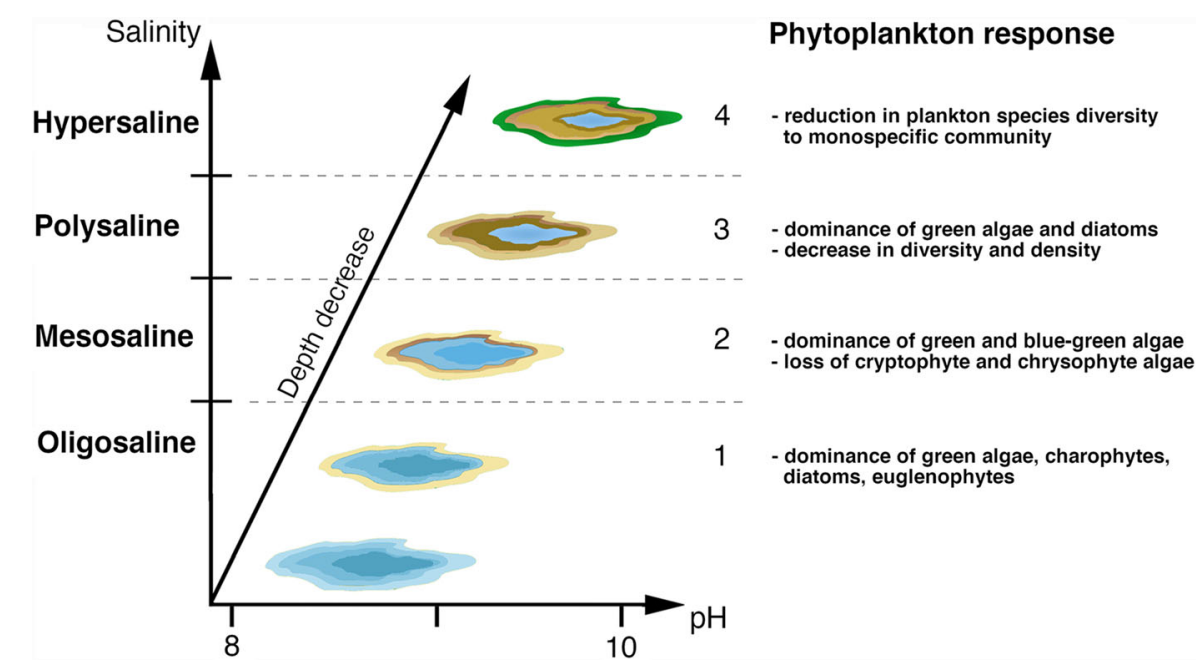

Fig. 1 Response of phytoplantkon community attributes to combined effect of salinity increase, pH increase and desiccation (modified from Fig. 3 in Afonina \& Tashlikova, 2020)

based on Dunaliella e.g. in Camargue, Rhône Delta, France (Britton et al., 1986) but these cases will not be discussed here since these water bodies typically get seawater. In both salt and saline-alkaline lakes birds act as top predators of the "simple" food webs. The case is similar in the very shallow soda pans of the Carpathian basin: a diverse assemblage of migratory aquatic birds have a profound impact on the nutrient load and -cycling of the whole ecosystem (Boros et al., 2008a, b; Horváth et al., 2013) especially that many dries out periodically and therefore cannot support fish populations.

Relationship of Reynolds' functional groups to assemblage composition of extreme habitats

Development of the functional group concept has long roots starting with Reynolds' publications (Reynolds $1980,1984)$ and finally summarized in Reynolds et al. (2002) has doubtlessly been a milestone in phytoplankton ecology. When developing the concept, the following constraints were considered: depth of the surface mixed layer, mean daily irradiance levels, water temperature, the concentrations of soluble reactive phosphorus, dissolved inorganic nitrogen, soluble reactive silicon, dissolved carbon dioxide and the proportion of the water processed each day by rotiferan and crustacean zooplankton. Evidently, the functional group concept was developed for "average conditions" as seen, for example, from that salinity was not listed. During the preparation of this paper, we tried to link species occurring in extreme environments to the functional group concept, however with little success especially at the margins of the variable ranges. This is not surprising, since adaptation to such conditions often needs special biochemical settings, which are species-specific. Substantial ecophysiological differences occur within species (ecotypes; see e.g. Piccini et al., 2011; Miotto et al., 2017), and within species of the same genera (Kust et al., 2015; Lengyel et al., 2020)_all belonging to the same functional group. Minor differences between ecophysiological tolerance levels may basically determine dispersal opportunities (Lengyel et al., 2020) or even competition between species of different functional groups can be strain dependent (Marinho et al., 2013). Additionally, the food-web structure is markedly different in such lakes with absence or of subordinate role of common grazers (like rotifers and crustaceans). These considerations were not meant for being critics for Reynolds' functional group concept. No theory is known in natural science, which could be applied outside its scales. Humankind could never reach a planet far away from the Earth using Newton's mechanics and, in return, if we experience that a snooker table is not flat enough it is much wiser to call for a joiner than to start space warp calculations. 
Species number, compositional diversity, equilibrium/steady-state

Due to the inhomogeneity of species-specific data and rarity of "complete" species list along with comparable abundance (biomass) data, it is practically hopeless to outline general environmental variablespecies number relationships for the afore discussed environmental constraints not talking about other habitat features (e.g. lake size, see Borics et al., 2018), which may strongly interfere with species richness. However, plenty of case studies demonstrated species number decrease towards the edges of variable ranges.

As was demonstrated earlier, along the $\mathrm{pH}$ range both extreme edges limit species number to 1-3 species: to an Ochromonas-Chlamydomonas assemblage in acidic edge, and to mostly Limnospira and Anabaenopsis assemblage in alkaline (Ballot et al., 2004, 2005; Tittel et al., 2005; Krienitz et al., 2013a). A marked difference between hyperacidic and hyperalkaline conditions is the productivity of phytoplankton in these lakes: very high phytoplankton biomass can develop in the latter ones, while acidic lakes are often dystrophic with low phytoplankton biomass. High level of salinity selects ultimately to a monospecific phytoplankton, Dunaliella. However, very low salt content does not seem to influence species number as exemplified, e.g. by the species rich phytoplankton of Lake Baikal with its low conductivity (Kozhov, 2013). Continuous deep mixing appears also highly selective leading to monospecific phytoplankton (e.g. Brookes et al., 2013).

Compositional diversity as measured by the Shannon-Wiener function depends both on the species number and on the evenness: distribution of species within the whole sample (Ortiz-Burgos, 2016). As species number is low in extreme environments, compositional diversity is also low. Same for the evenness: when one or some (few) species are highy dominant, diversity is also low. As a consequence, a common feature of extreme environments is the low compositional diversity.

Conditions for establishment of low-diversity equilibrium/steady state phytoplankton assemblages was thoroughy discussed during the IAP workshop organized in Castelbuono Italy/Sicily, 2002 (NaselliFlores et al., 2003). By definition, such assemblages can be identified if no more than 3 species contribute at least $80 \%$ to total biomass and this condition prevails for at least 3 weeks (Sommer et al., 1993). Conclusion of these studies was that development of equilibrium phases in phytoplankton assemblages of "average lakes" is rare and if occurs, it is the most probable late summers with dominance of a species belonging to cyanobacteria. The underlaying reason is either a specialized strategy (diurnal migration between the surface and the sediment combined with tolerance of high light; Microcystis) or high level of shade adaptation [Raphidiopsis raciborskii (Wołoszyńska) Aguilera, Berrendero Gómez, Kastovsky, Echenique \& Salerno; Planktothrix agardhii (Gomont) Anagnostidis \& Komárek], but other explanations are also abundant.

As follows from the low diversity (low species number combined with high dominance of one or few species) in extreme lakes, equilibrium phases must be presistent or at least prevail during most of the time. Cyanobacterial dominance in extreme lake environments appears typical in saline-alkaline lakes and such equilibria last long. For example, Limnospira fusiformis and Anabaenopsis sp. contributed to total biomass for at least 7 years in Lake Oloiden, East Africa (Krienitz et al., 2013a) and a Limnospira fusiformis, Anabaenopsis sp. and Cyanospira assemblage for 6 years in Lake Nakuru (Krienitz et al., 2013b). However, cyanobacterial equilibria are not typical in lakes with other kinds of extremes. In acidic coal-mine lakes the Ochromonas-Chlamydomonas assemblage is frequent and even if the assemblage consists of more than two species(complex), dominance of only several is high. For example, in the volcanic-acidic Lake Caviahue, Patagonia, 5 species (Chlamydomonas sp., Viridella sp., Chloridella sp., Keratococcus rhaphidioides (Hansgirg) Pascher and Euglena mutabilis F. Schmitz) were recorded in the phytoplankton but during the 6 years of the observations in no case more than 3 of the above species contributed to more than $80 \%$ of phytoplankton biomass (Beamud et al., 2010). Therefeore, even if species contributions changed the equilibrium was persistent.

In conclusion, at the edge of extremes single (stress tolerant) species with appropriate biochemical and physiological adaptations are selected and monodominant phytoplankton often occurs. Under less but still extreme conditions permanent equilibria persist-in many cases over years. Long lasting equilibria make quite a contrast to ,average” lakes where these are rare 
and ephemeral. Phytoplankton in extreme environments are similarly exposed to variation of seasons and weather than „average lakes”. However, the single (or combined) extreme condition that shapes their species composition and dominance levels appears to be much stronger than stochasticity of common disturbances and this leads to their biotic permanency.

It is implortant, however, to realize that establishment of equilibrium/steady states imply different mechanisms in ,avarage” and extreme lakes. In common cases the ephemeral equilibrium is resulted from competitive exclusion (Naselli-Flores et al., 2003 and references cited there) and under extreme conditions individual physiological adaptation of some (one or few) species' stress tolerace is the main driver.

It does not mean that these phytoplankton assemblages would not change. They do, depending on severely extreme conditions and, as ecophysiological research documented, minor differences in ecophysiological properites may change competitve abilities under the threat of the climate change (Lengyel et al., 2020).

Acknowledgements We thank the helpful comments by two external reviewers on the originally submitted version of this paper. This study was supported by the Hungarian National Research Development and Innovation Office (NKFIH K120595). Open access funding was provided by the University of Pannonia. We thank Franciska M. Tóth for her help in the graphical adaptation.

Open Access This article is licensed under a Creative Commons Attribution 4.0 International License, which permits use, sharing, adaptation, distribution and reproduction in any medium or format, as long as you give appropriate credit to the original author(s) and the source, provide a link to the Creative Commons licence, and indicate if changes were made. The images or other third party material in this article are included in the article's Creative Commons licence, unless indicated otherwise in a credit line to the material. If material is not included in the article's Creative Commons licence and your intended use is not permitted by statutory regulation or exceeds the permitted use, you will need to obtain permission directly from the copyright holder. To view a copy of this licence, visit http://creativecommons.org/licenses/by/4.0/.

\section{References}

Afonina, Y. E. \& N. Tashlikova, 2020. Fluctuations in plankton community structure of endorheic soda lakes of southeastern Transbaikalia (Russia). Hydrobiologia 847: 1383-1398.

Allende, L., G. Tell, H. Zagarese, A. Torremorell, D. Pérez, J. Bustingorry, R. Escaray \& I. Izaguirre, 2009. Phytoplankton and primary production in clear-vegetated, inorganic-turbid, and algal-turbid shallow lakes from the pampa plain (Argentina). Hydrobiologia 624: 45-60.

Asencio, A. D., 2013. Permanent salt evaporation ponds in a semi-arid Mediterranean region as model systems to study primary production processes under hypersaline conditions. Estuarine, Coastal and Shelf Science 124: 24-33.

Balogh, V., K. E. Koncz \& L. Vörös, 2000. An empirical model describing the contribution of colour, algae and particles to the light climate of shallow lakes. Verhandlungen der internationale Vereinigung für theoretische und angewandte Limnologie 27: 2678-2681.

Ballot, A., L. Krienitz, K. Kotut, C. Wiegand, J. S. Metcalf, G. A. Codd \& S. Pflugmacher, 2004. Cyanobacteria and cyanobacterial toxins in three alkaline Rift Valley lakes of Kenya-Lakes Bogoria, Nakuru and Elmenteita. Journal of Plankton Research 26: 925-935.

Ballot, A., L. Krienitz, K. Kotut, C. Wiegand \& S. Pflugmacher, 2005. Cyanobacteria and cyanobacterial toxins in the alkaline crater lakes Sonachi and Simbi, Kenya. Harmful Algae 4: 139-150.

Barbosa, F. A. R. \& J. Padisák, 2002. The forgotten lake stratification pattern: atelomixis, and its ecological importance. Verhandlungen der internationale Vereinigung für theoretische und angewandte Limnologie 28: 1385-1395.

Barbosa, L. G., P. M. Barbosa \& F. A. R. Barbosa, 2011. Vertical distribution of phytoplankton functional groups in a tropical shallow lake: driving forces on a diel scale. Acta Limnologica Brasiliensia 23: 63-73.

Barbosa, L. G., F. A. R. Barbosa \& C. E. Bicudo, 2013. Adaptive strategies of desmids in two tropical monomictic lakes in southeast Brazil: do morphometric differences promote life strategies selection? Hydrobiologia 710: 157-171.

Barone, R., G. Castelli \& L. Naselli-Flores, 2010. Red sky at night cyanobacteria delight: the role of climate in structuring phytoplankton assemblage in a shallow, Mediterranean lake (Biviere di Gela, southeastern Sicily). Hydrobiologia 639: 43-53.

Beamud, S. G., M. M. Diaz \& F. L. Pedrozo, 2010. Nutrient limitation of phytoplankton in a naturally acidic lake (Lake Caviahue, Argentina). Limnology 11: 103-113.

Bell, E. M., G. Weithoff \& U. Gaedke, 2006. Temporal dynamics and growth of Actinophrys sol (Sarcodina: Heliozoa), the top predator in an extremely acidic lake. Freshwater Biology 51: 1149-1161.

Belovsky, G. E., D. Stephens, C. Perschon, P. Birdsey, D. Paul, D. Naftz, R. Baskin, C. Larson, C. Mellison, J. Luft \& R. Mosley, 2011. The Great Salt Lake ecosystem (Utah, USA): long term data and a structural equation approach. Ecosphere 2(3): 1-40.

Beulker, C., D. Lessmann \& B. Nixdorf, 2003. Aspects of phytoplankton succession and spatial distribution in an 
acidic mining lake (Plessa 117, Germany). Acta Oecologica 24: $25-31$.

Bernard, C., A. Escalas, N. Villeriot, H. Agogué, M. Hugoni, C. Duval, C. Carré, P. Got, G. Sarazin, D. Jézéquel, C. Leboulanger, V. Grossi, M. Ader \& M. Troussellier, 2019. Very low phytoplankton diversity in a tropical saline-alkaline lake, with co-dominance of Arthrospira fusiformis (Cyanobacteria) and Picocystis salinarum (Chlorophyta). Microbial Ecology 78: 603-617.

Blouin, A. C., 1989. Patterns of plankton species, $\mathrm{pH}$ and associated water chemistry in Nova Scotia lakes. Water, Air, and Soil Pollution 46: 343-358.

Borics, G., I. Grigorszky, J. Padisák, F. A. R. Barbosa \& Z. Z. Doma, 2005. Dinoflagellates from tropical Brazilian lakes with description of Peridinium brasiliense sp. nov. Algological Studies 118: 47-61.

Borics, G., G. Várbíró \& J. Padisák, 2013. Disturbance and stress-different meanings in ecological dynamics? Hydrobiologia 711: 1-7.

Borics, G., B. Tóthmérész, G. Várbíró, I. Grigorszky, A. Czébely \& J. Görgényi, 2018. Functional phytoplankton distribution in hypertrophic systems across water body size. Hydrobiologia 764: 81-90.

Boros, E., L. Forró, G. Gere, O. K. Kiss, L. Vörös \& S. Andrikovics, 2008a. The role of aquatic birds in the regulation of trophic relationships of continental soda pans in Hungary. Acta Zoologica Academiae Scientiarum Hungaricae 54: 189-206.

Boros, E., T. Nagy, C. Pigniczki, L. Kotymán, K. V. Balogh \& L. Vörös, 2008b. The effect of aquatic birds on the nutrient load and water quality of soda pans in Hungary. Acta Zoologica Academiae Scientiarum Hungaricae 54: 207-224.

Boros, E., Z. Horváth, D. Wolfram \& L. Vörös, 2014. Salinity and ionic composition of the shallow astatic soda pans in the Carpathian Basin. Annales de Limnologie-International Journal of Limnology 50: 59-69.

Boros, E., K. V. Balogh, L. Vörös \& Z. Horváth, 2017. Multiple extreme environmental conditions of intermittent soda pans in the Carpathian Basin (Central Europe). Limnologica 62: 38-46.

Borowitzka, L. J., 1981. The microflora. Adaptations to life in extremely saline lakes. Hydrobiologia 81: 33-46.

Bortolini, J. C., S. Train \& L. C. Rodrigues, 2016. Extreme hydrological periods: effects on phytoplankton variability and persistence in a subtropical floodplain. Hydrobiologia 763: 223-236.

Bouffard, D., R. E. Zdorovennov, G. E. Zdorovennova, N. Pasche, A. Wüest \& A. Y. Terzhevik, 2016. Ice-covered Lake Onega: effects of radiation on convection and internal waves. Hydrobiologia 780: 21-36.

Bouffard, D., G. Zdorovennova, S. Bogdanov, T. Efremova, S. Lavanchy, N. Palshin, A. Terzhevik, L. R. Vinnå, S. Volkov, A. Wüest \& R. Zdorovennov, 2019. Under-ice convection dynamics in a boreal lake. Inland Waters 9: 142-161.

Britton, R. H., E. R. de Groot \& A. R. Johnson, 1986. The daily cycle of feeding activity of the Greater Flamingo in relation to the dispersion of the prey Artemia. Wildfowl 37: 151-155.
Brookes, J. D., K. R. O’Brien, M. A. Burford, D. Bruesewitz, B. R. Hodges, C. McBride \& D. P. Hamilton, 2013. Effects of diurnal vertical mixing and stratification on phytoplankton productivity in geothermal Lake Rotowhero, New Zealand. Inland Waters 3: 369-376.

Cabrera, S., M. Lopez \& B. Tartarotti, 1997. Phytoplankton and zooplankton response to ultraviolet radiation in a highaltitude Andean lake: short-versus long-term effects. Journal of Plankton Research 19: 1565-1582.

Calvo, S., R. Barone, L. Naselli Flores, C. Fradà Orestano, G. Dongarrà \& G. Genchi, 1993. Limnological studies on lakes and reservoirs of Sicily. II Naturista Siciliano 27: 292.

Carey, C. C., K. C. Weathers \& K. L. Cottingham, 2008. Gloeotrichia echinulata blooms in an oligotrophic lake: helpful insights from eutrophic lakes. Journal of Plankton Research 30: 893-904.

Castenholz, R. W., 1969. Thermophilic blue-green algae and the thermal environment. Bacteriological Reviews 33: 476-504.

Cellamare, M., C. Duval, Y. Drelin, C. Djediat, N. Touibi, H. Agogué, C. Leboulanger; M. Ader \& C. Bernard, 2018. Characterization of phototrophic microorganisms and description of new cyanobacteria isolated from the salinealkaline crater-lake Dziani Dzaha (Mayotte, Indian Ocean). FEMS Microbiology Ecology 94/8: fly108.

Cellamare, M., A. M. Lancon, M. Leitão, L. Cerasino, U. Obertegger \& G. Flaim, 2016. Phytoplankton functional response to spatial and temporal differences in a cold and oligotrophic lake. Hydrobiologia 764: 199-209.

Costas, E., A. Flores-Moya \& V. López-Rodas, 2008. Rapid adaptation of phytoplankters to geothermal waters is achieved by single mutations: were extreme environments 'Noah's Arks' for photosynthesizers during the Neoproterozoic 'snowball Earth'? New Phytologist 180: 922-932.

Cózar, A., M. Bruno, N. Bergamino, B. Úbeda, L. Bracchini, A. M. Dattilo \& S. A. Loiselle, 2012. Basin-scale control on the phytoplankton biomass in Lake Victoria, Africa. PLoS ONE 7: e29962.

Crisci, C., R. Terra, J. P. Pacheco, B. Ghattas, M. Bidegain, G. Goyenola, J. J. Lagomarsino, G. Méndez \& N. Mazzeo, 2017. Multi-model approach to predict phytoplankton biomass and composition dynamics in a eutrophic shallow lake governed by extreme meteorological events. Ecological Modelling 360: 80-93.

Cronberg, G., G. Lindmark \& S. Björk, 1988. Mass development of the flagellate Gonyostomum semen (Raphidophyta) in Swedish forest lakes: an effect of acidification? Hydrobiologia 161: 217-236.

Crossetti, L. O., D. de Campos Bicudo, L. M. Bini, R. B. DalaCorte, C. Ferragut \& C. E. de Mattos Bicudo, 2019. Phytoplankton species interactions and invasion by Ceratium furcoides are influenced by extreme drought and waterhyacinth removal in a shallow tropical reservoir. Hydrobiologia 831: 71-85.

Degefu, F. \& M. Schagerl, 2015. The phytoplankton community of tropical high-mountain crater lake Wonchi, Ethiopia. Hydrobiologia 755: 197-208.

Devercelli, M., 2010. Changes in phytoplankton morpho-functional groups induced by extreme hydroclimatic events in 
the Middle Paraná River (Argentina). Hydrobiologia. 639: 5-19.

Dokulil, M. \& J. Padisák, 1994. Long-term compositional response of phytoplankton in a shallow, turbid environment, Neusiedlersee, Austria/Hungary. Hydrobiologia 275-276: 125-137.

Drakare, S., P. Blomqvist, A. Bergström \& M. Jansson, 2003. Relationships between picophytoplankton and environmental variables in lakes along a gradient of water colour and nutrient content. Freshwater Biology 48: 729-740.

Esmaeili Dahesht, L., H. Negarestan, A. Eimanifar, F. Mohebbi \& R. Ahmadi, 2010. The fluctuations of physicochemical factors and phytoplankton populations of Urmia Lake, Iran. Iranian Journal of Fisheries Sciences 9: 368-381.

Fanjing, K., J. Qinxian, E. Jia \& Z. Mianping, 2009. Characterization of a eukaryotic picoplankton alga, strain DGN$\mathrm{Z1}$, isolated from a soda lake in inner Mongolia, China. Natural Resources asd Environmental Issues 15: 185-189.

Fawley, M. W., I. Jameson \& K. P. Fawley, 2015. The phylogeny of the genus Nannochloropsis (Monodopsidaceae, Eustigmatophyceae), with descriptions of $N$. australis sp. nov. and Microchloropsis gen. nov. Phycologia 54: $545-552$.

Fetahi, T., M. Schagerl \& S. Mengistou, 2010. Key drivers for phytoplankton composition and biomass in an Ethiopian highland lake. Limnologica 46: 77-83.

Findlay, D. L., 2003. Response of phytoplankton communities to acidification and recovery in Killarney Park and the Experimental Lakes Area, Ontario. AMBIO 32: 190-196.

García-Balboa, C., B. Baselga-Cervera, A. García-Sanchez, J. M. Igual, V. Lopez-Rodas \& E. Costas, 2013. Rapid adaptation of microalgae to bodies of water with extreme pollution from uranium mining: an explanation of how mesophilic organisms can rapidly colonise extremely toxic environments. Aquatic Toxicology 144: 116-123.

Gracia-Pichel, F., 1994. A model for internal self-shading in planktonic organisms and its implications for the usefulness of ultra-violet sunscreens. Limnology and Oceanography 39: 1704-1717.

Górniak, A., 2016. A new version of the Hydrochemical Dystrophy Index to evaluate dystrophy in lakes. Ecological Indicators 78: 566-573.

Graham, J. M., A. D. Kent, G. H. Lauster, A. C. Yannarell, L. E. Graham \& E. W. Triplett, 2004. Seasonal dynamics of phytoplankton and planktonic protozoan communities in a northern temperate humic lake: diversity in a dinoflagellate dominated system. Microbial Ecology 48: 528-540.

Grant, W. D., R. T. Gemmel \& T. J. McGenity, 1998. Halophyles. In Horikoshi, H. \& W. D. Grant (eds), Extremophiles: Microbial Life in Extreme Environments: 93-132. Wiley, New York.

Grime, J. P., 2001. Plant Strategies, Vegetation Processes, and Ecosystem Properties. Wiley, Chichester.

Gross, W., 2000. Ecophysiology of algae living in highly acidic environments. Hydrobiologia 433: 31-37.

Gunkel, G. \& C. Beulker, 2009. Limnology of the Crater Lake Cuicocha, Ecuador, a cold water tropical lake. International Review of Hydrobiology 94: 103-125.

Halac, S., M. Felip, L. Camarero, S. Sommaruga-Wograth, E. Psenner, C. Jordi \& R. Sommaruga, 1997. An in situ enclosure experiment to test the solar UVB impact on plankton in a high-altitude mountain lake. I. Lack of effect on phytoplankton species composition and growth. Journal of Plankton Research 19: 1671-1686.

Hargraves, P. E. \& R. Víquez, 1981. Dinoflagellate abundance in the Laguna Botos, Poás Volcano, Costa Rica. Revista de Biología Tropical 29: 257-264.

Havens, K., H. Paerl, E. Phlips, M. Zhu, J. Beaver \& A. Srifa, 2016. Extreme weather events and climate variability provide a lens to how shallow lakes may respond to climate change. Water: 8: art. nr. 229.

Hecky, R. E. \& P. Kilham, 1973. Diatoms in alkaline, saline lakes: ecology and geochemical implications 1. Limnology and Oceanography 18: 53-71.

Hollibaugh, J. T., P. S. Wong, N. Bano, S. K. Pak, E. M. Prager \& C. Orrego, 2001. Stratification of microbial assemblages in Mono Lake, California, and response to a mixing event. Hydrobiologia 466: 45-60.

Holopainen, I. J., A. L. Holopainen, E. Huitu, M. Rahkola-Sorsa \& P. Zingel, 2008. The pelagic food web in forest lakes affected by alkaline mining waste in NW Russia. Estonian Journal of Ecology 57: 217-228.

Hornström, E., 2002. Phytoplankton in 63 limed lakes in comparison with the distribution in 500 untreated lakes with varying $\mathrm{pH}$. Hydrobiologia 470: 115-126.

Horváth, Z., X. F. Vad, L. Vörös \& E. Boros, 2013. The keystone role of anostracans and copepods in European soda pans during the spring migration of waterbirds. Freshwater Biology 58: 430-440.

Hosseini Tafreshi, A. \& M. Shariati, 2009. Dunaliella biotechnology: methods and applications. Journal of Applied Microbiology 107: 14-35.

Incagnone, G., F. Marrone, L. Robba, R. Barone \& L. NaselliFlores, 2015. How do freshwater organisms cross the "dry ocean"? A review on passive dispersal and colonization processes with a special focus on temporary ponds. Hydrobiologia 750: 103-123.

Ionescu, V., M. Năstăsescu, L. Spiridon \& V. A. Bulgăreanu, 1998. The biota of Romanian saline lakes on rock salt bodies: a review. International Journal of Salt Lake Research 7: 45-80.

Istvánovics, V., K. Petterson, M. A. Rodrgio, D. Pierson, J. Padisák \& W. Colom, 1993. Gloeotrichia echinulata, a colonial cyanobacterium with a unique phosphorus uptake and life strategy. Journal of Plankton Research 15: 531-552.

Izaguirre, I., L. Allende, R. Escaray, J. Bustingorry, G. Pérez \& G. Tell, 2012. Comparison of morpho-functional phytoplankton classifications in human-impacted shallow lakes with different stable states. Hydrobiologia. 698: 203-226.

Izaguirre, I., L. Allende \& M. R. Schiaffino, 2020. Phytoplankton in Antarctic lakes: biodiversity and main ecological features. Hydrobiologia. https://doi.org/10.1007/ s10750-020-04306-x.

Jacobsen, B. A., 1994. Bloom formation of Gloeotrichia echinulata and Aphanizomenon flos-aquae in a shallow, eutrophic, Danish lake. Hydrobiologia 289: 193-197.

Jasser, I., 1997. The dynamics and importance of picoplankton in shallow, dystrophic lake in comparison with surface waters of two deep lakes with contrasting trophic status. Hydrobiologia 342-343: 87-93. 
Jewson, D. H., N. G. Granin, A. A. Zhdanov \& R. Y. Gnatovsky, 2009. Effect of snow depth on under-ice irradiance and growth of Aulacoseira baicalensis in Lake Baikal. Aquatic Ecology 43: 673-679.

Ji, F., Y. K. Wang, G. Li, Y. G. Zhou \& R. J. Dong, 2015. Isolation of microalgae with growth restriction and nutrient removal from alkaline wastewater. International Journal of Agricultural and Biological Engineering 8(6): 62-68.

Kamjunke, N., U. Gaedke, G. Weithoff \& E. M. Bell, 2004. Strong vertical differences in the plankton composition of an extremely acidic lake. Archiv für Hydrobiologie 161: 289-306.

Kasprzak, P., T. Shatwell, M. O. Gessner, T. Gonsiorczyk, G. Kirillin, G. Selmeczy, J. Padisák \& C. Engelhardt, 2017. Extreme weather event triggers cascade towards extreme turbidity in a clear-water lake. Ecosystems 20: 1407-1420.

Kebede, E., 1997. Response of Spirulina platensis (=Arthrospira fusiformis) from Lake Chitu, Ethiopia, to salinity stress from sodium salts. Journal of Applied Phycology 9: 551-558.

Kebede, E. \& G. Ahlgren, 1996. Optimum growth conditions and light utilization efficiency of Spirulina platensis (=Arthrospira fusiformis) (Cyanophyta) from Lake Chitu, Ethiopia. Hydrobiologia 332: 99-109.

Kenttämies, K., 1994. The effect of acidic deposition on waters. In Acidification of inland waters. The third Soviet-Karelian symposium on water problems, Joensuu, Finland, 37 June 1991. Publications of the National Board of Water and the Environment, ser. A 188. Helsinki: 9-41.

Korneva, L. G., 2001. Ecological aspects of mass development of Gonyostomum semen (Ehr.) Dies. (Raphidophyta). International Journal on Algae 3: 40-54.

Kozak, A., R. Gołdyn, R. Dondajewska, K. KowalczewskaMadura \& T. Holona, 2017. Changes in phytoplankton and water quality during sustainable restoration of an urban lake used for recreation and water supply. Water 9: 713.

Kozhov, M., 2013. Lake Baikal and its life. Springer Science \& Business Media, Berlin.

Krienitz, L., 2018. Lesser Flamingos. Descendants of Phoenix. Springer Nature, Berlin.

Krienitz, L. \& K. Kotut, 2010. Fluctuating algal food populations and the occurrence of lesser flamingos (Phoeniconaias minor) in three Kenyan rift valley lakes 1. Journal of Phycology 46: 1088-1096.

Krienitz, L., P. K. Dadheech \& K. Kotut, 2013a. Mass developments of a small sized ecotype of Arthrospira fusiformis in Lake Oloidien, Kenya, a new feeding ground for Lesser Flamingos in East Africa. Fottea, Olomouc 13: 215-225.

Krienitz, L., P. K. Dadheech \& K. Kotut, 2013b. Mass developments of the cyanobacteria Anabaenopsis and Cyanospira (Nostocales) in the soda lakes of Kenya: ecological and systematic implications. Hydrobiologia 703: 79-93.

Krienitz, L., D. Krienitz, P. K. Dadheech, T. Hübener, K. Kotut, W. Luo, K. Teubner \& W. D. Versfeld, 2016. Food algae for Lesser Flamingos: a stocktaking. Hydrobiologia 775 : 21-50.

Kust, A., E. Kozlíková-Zapomělová, J. Mareš \& K. Řeháková, 2015. A detailed morphological, phylogenetic and ecophysiological analysis of four benthic Anabaena (Nostocales, Cyanobacteria) strains confirms deep hetero-geneity within the genus. Fottea, Olomouc 15: 191-202.
Kwiatkowski, R. E. \& J. C. Roff, 1976. Effects of acidity on the phytoplankton and primary productivity of selected northern Ontario lakes. Canadian Journal of Botany 54: 2546-2561.

Leigh, C., A. Watkinson \& M. Burford, 2015. Effects of extreme inflows on the water quality and phytoplankton of seven reservoirs in subtropical Australia. Inland Waters 5: 240-252.

Lengyel, E., A. W. Kovács, J. Padisák \& C. Stenger-Kovács, 2015. Photosynthetic characteristics of the benthic diatom species Nitzschia frustulum (Kützing) Grunow isolated from a soda pan along temperature-, sulfate-and chloride gradients. Aquatic Ecology 49: 401-416.

Lengyel, E., T. Pálmai, J. Padisák \& C. Stenger-Kovács, 2019. Annual hydrological cycle of environmental variables in astatic soda pans (Hungary). Journal of Hydrology 575: 1188-1199.

Lengyel, E., D. Lázár, A. J. Trájer \& C. Stenger-Kovács, 2020. Climate change projections for Carpathian soda pans on the basis of photosynthesis evidence from typical diatom species. Science of The Total Environment 710: 136241.

Lepistö, L. \& U. Rosenström, 1998. The most typical phytoplankton taxa in four types of boreal lakes. Hydrobiologia 369: 89-97.

Lepistö, L., S. Antikainen \& J. Kivinen, 1994. The occurrence of Gonyostomum semen (Ehr.) Diesing in Finnis lakes. Hydrobiologia 273: 1-8.

Lessmann, D., A. Fyson \& B. Nixdorf, 2010. Phytoplankton of the extremely acidic mining lakes of Lusatia (Germany) with $\mathrm{pH} \leq 3$. Hydrobiologia 433: 123-128.

Lewin, R. A., L. Krienitz, R. Goericke, H. Takeda \& D. Hepperle, 2000. Picocystis salinarum gen. et sp. nov. (Chlorophyta): a new picoplanktonic green alga. Phycologia 39: 560-565.

Lewis Jr., W. M., 1978. Dynamics and succession of the phytoplankton in a tropical lake: Lake Lanao, Philippines. The Journal of Ecology 1: 849-880.

Lopez-Archilla, A. I., D. Moreira, P. López-García \& C. Guerrero, 2004. Phytoplankton diversity and cyanobacterial dominance in a hypereutrophic shallow lake with biologically produced alkaline $\mathrm{pH}$. Extremophiles 8: 109-115.

Low-Décarie, E., G. F. Fussmann, A. J. Dumbrell \& G. Bell, 2016. Communities that thrive in extreme conditions captured from a freshwater lake. Biology Letters 12: 20160562.

Mádl-Szőnyi, J. \& J. Tóth, 2009. A hydrogeological type section for the Duna-Tisza Interfluve, Hungary. Hydrogeology Journal 17: 961-980.

Marcarelli, A. M., W. A. Wurtsbaugh \& O. Griset, 2006. Salinity controls phytoplankton response to nutrient enrichment in the Great Salt Lake, Utah, USA. Canadian Journal of Fisheries and Aquatic Sciences 63: 2236-2248.

Marchant, H. J., A. T. Davidson \& G. J. Kelly, 1991. UV-B protecting compounds in the marine alga Phaeocystis pouchetti from Antartica. Marine Biology 109: 391-395.

Marinho, M. M., M. B. Souza \& M. Lürling, 2013. Light and phosphate competition between Cylindrospermopsis raciborskii and Microcystis aeruginosa is strain dependent. Microbial Ecology 66: 479-488. 
Melack, J. M., 1988. Primary producer dynamics associated with evaporative concentration in a shallow, equatorial soda lake (Lake Elmenteita, Kenya). Hydrobiologia 158: $1-14$.

Mihaljević, M., D. Špoljarić, F. Stević, V. Cvijanović \& B. H. Kutuzović, 2010. The influence of extreme floods from the River Danube in 2006 on phytoplankton communities in a floodplain lake: shift to a clear state. LimnologicaEcology and Management of Inland Waters 40: 260-268.

Miotto, M. C., L. D. Costa, D. M. Brentano, C. Nader, L. dos Santos Souza, P. D. Gressler, R. Laudares-Silva, J. S. Yunes, J. B. Barufi \& L. R. Rörig, 2017. Ecophysiological characterization and toxin profile of two strains of Cylindrospermopsis raciborskii isolated from a subtropical lagoon in Southern Brazil. Hydrobiologia 802: 97-113.

Naselli-Flores, L. \& J. Padisák, 2016. Blowing in the wind: how many roads can a phytoplanktont walk down? A synthesis on phytoplankton biogeography and spatial processes. Hydrobiologia 764: 303-313.

Naselli-Flores, L., J. Padisák, M. T. Dokulil \& I. Chorus, 2003. Equilibrium/steady-state concept in phytoplankton ecology. Hydrobiologia 502: 395-403.

Naselli-Flores, L., T. Zohary \& J. Padisák, 2020. Life in suspension and its impact on phytoplankton morphology: an homage to Colin S. Reynolds. Hydrobiologia. https://doi. org/10.1007/s10750-020-04217-x.

Neale, P. J. \& J. C. Priscu, 1995. The photosynthetic apparatus of phytoplankton from a perennially ice-covered Antarctic lake: acclimation to an extreme shade environment. Plant and Cell Physiology 36: 253-263.

Nixdorf, B., U. Mischke \& D. Leßmann, 1998. Chrysophytes and Chlamydomonads: pioneer colonists in extremely acidic mining lakes $(\mathrm{pH}<3)$ in Lusatia (Germany). Hydrobiologia 369: 315-327.

Oduor, S. O. \& M. Schagerl, 2007. Phytoplankton photosynthetic characteristics in three Kenyan Rift Valley salinealkaline lakes. Journal of Plankton Research 29: 1041-1050.

Oren, A., 2014. The ecology of Dunaliella in high-salt environments. Journal of Biological Research-Thessaloniki 21: art. Nr. 23.

Oren, A., 1999. Microbiological studies in the Dead Sea: future challenges toward the understanding of life at the limit of salt concentrations. Hydrobiologia 405: 1-9.

Oren, A. \& N. Ben-Yosef, 1997. Development and spatial distribution of an algal bloom in the Dead Sea: a remote sensing study. Aquatic Microbiology Ecology 13: 219-223.

Oren, A., P. Gurevich, D. A. Anati, E. Barkan \& B. Luz, 1995. A bloom of Dunaliella parva in the Dead Sea in 1992: biological and biogeochemical aspects. Hydrobiologia 297: 173-185.

Ortiz-Burgos, S., 2016. Shannon-Weaver Diversity Index. In Kennish, M. J. (ed.), Encyclopedia of Estuaries: Encyclopedia of Earth Sciences Series. Springer, Dordrecht.

Özbay, H. \& S. Kılınç, 2008. Limnological studies on the transboundary Turkish soda lake: Lake Aktaş. Fresenius Environmental Bulletin 17: 722-731.

Padisák, J., 1992. Seasonal succession of phytoplankton in a large shallow lake (Balaton, Hungary): a dynamic approach to ecological memory, its possible role and mechanisms. Journal of Ecology 80: 217-230.

Padisák, J., 1993. Dynamics of phytoplankton in brown-water lakes enclosed with reed-belt (Fertö/Neusiedlersee; Hungary/Austria). Verhandlungen der Internationalen Vereinigung für theoretische und angewandte Limnologie 25: 675-679.

Padisák, J., L. O. Crossetti \& L. Naselli-Flores, 2009. Use and misuse in the application of the phytoplankton functional classification: a critical review with updates. Hydrobiologia 621: 1-19.

Padisák, J. \& M. Dokulil, 1994. Meroplankton dynamics in a saline, turbulent, turbid shallow lake (Neusiedlersee, Austria and Hungary). Hydrobiologia 289: 23-42.

Padisák, J., É. Hajnal, L. Krienitz, J. Lakner \& V. Üveges, 2010. Rarity, ecological memory, rate of floral change in phytoplankton-and the mystery of the Red Cock. Hydrobiologia 653: 45-67.

Padisák, J., É. Soróczki-Pintér \& Z. Rezner, 2003. Sinking properties of some phytoplankton shapes and relation of form resistance to morphological diversity of plankton: an experimental study. Hydrobiologia 500: 243-257.

Padisák, J., G. Vasas \& G. Borics, 2016. Phycogeography of freshwater phytoplankton-traditional knowledge and new molecular tools. Hydrobiologia 764: 3-27.

Pálffy, K., T. Felföldi, A. Mentes, H. Horváth, K. Márialigeti, E. Boros, L. Vörös \& B. Somogyi, 2014. Unique picoeukaryotic algal community under multiple environmental stress conditions in a shallow, alkaline pan. Extremophiles 18: 111-119.

Pallares, S., P. Arribas, D. T. Bilton, A. Millan \& J. Velasco, 2015. The comparative osmoregulatory ability of two water beetle genera whose species span the fresh-hypersaline gradient in inland waters (Coleoptera: Dytiscidae, Hydrophilidae). PLoS ONE 10: e0124299.

Pálmai, T., B. Szabó, K. Kotut, L. Krienitz \& J. Padisák, 2020. Ecophysiology of a successful phytoplankton competitor in the African flamingo lakes: the green alga Picocystis salinarum (Picocystophyceae). Journal of Applied Phycology 32: 1813-1825.

Pedrozo, F. L., L. Kelly, M. Pedrozo, F. L. L. Kelly, M. Diaz, P. Temporetti, G. Baffico, R. Kringel, K. Friese, M. Mages, W. Geller \& S. Woelfl, 2001. First results on the water chemistry, algae and trophic status of Andean acidic lake system of volcanic origin in Patagonia (Lake Caviahue). Hydrobiologia 452: 129-137.

Peduzzi, P., M. Gruber, M. Gruber \& M. Schagerl, 2014. The virus's tooth: cyanophages affect an African flamingo population in a bottom-up cascade. The ISME Journal 8: 1346-1351.

Perez, E. A., J. DeCosta \& K. E. Havens, 1994. The effects of nutrient addition and $\mathrm{pH}$ manipulation in bag experiments on the phytoplankton of a small acidic lake in West Virginia, USA. Hydrobiologia 291: 93-103.

Pernica, P., R. L. North \& H. M. Baulch, 2017. In the cold light of day: the potential importance of under-ice convective mixed layers to primary producers. Inland Waters 7: 138-150.

Piccini, C., L. Aubriot, A. Fabre, V. Amaral, M. GonzálezPiana, A. Giani, C. C. Figueredo, L. Vidal, C.- Kruk \& S. Bonilla, 2011. Genetic and eco-physiological differences 
of South American Cylindrospermopsis raciborskii isolates support the hypothesis of multiple ecotypes. Harmful Algae 10: 644-653.

Platt, T., C. L. Gallegos \& W. G. Harrison, 1980. Photoinibition of photosynthesis in natural assemblages of marine phytoplankton. Journal of Marine Research 38: 687-701.

Raven, J. A., L. A. Ball, J. Beardall, M. Giordano \& S. C. Maberly, 2005. Algae lacking carbon-concentrating mechanisms. Canadian Journal of Botany 83: 879-890.

Rengefors, K., G. A. Weyhenmeyer \& I. Bloch, 2012. Temperature as a driver for the expansion of the microalga Gonyostomum semen in Swedish lakes. Harmful Algae 18: $65-73$.

Reynolds, C. S., 1980. Phytoplankton assemblages and their periodicity in stratifying lake systems. Holarctic Ecology 3: 141-159.

Reynolds, C. S., 1984. Phytoplankton periodicity: the interactions of form, function and environmental variability. Freshwater Biology 14: 111-142.

Reynolds, C. S., 1997. Vegetation Processes in the Pelagic: A Model for Ecosystem Theory. Ecology Institute, Oldendorf/Luhe.

Reynolds, C. S., 2007. Variability in the provision and function of mucilage in phytoplankton: facultative responses to the environment. Hydrobiologia 578: 37-45.

Reynolds, C. S., V. Huszar, C. Kruk, L. Naselli-Flores \& S. Melo, 2002. Towards a functional classification of the freshwater phytoplankton. Journal of Plankton Research 24: 417-428.

Reynolds, C. S., J. Padisák \& I. Kóbor, 1993a. A localized bloom of Dinobryon sociale in Lake Balaton: some implications for the perception of patchiness and the maintenance of species richness. Abstracta Botanica 17: 251-260.

Reynolds, C. S., J. Padisák \& U. Sommer, 1993b. Intermediate disturbance in the ecology of phytoplankton and the maintenance of species diversity: a synthesis. Hydrobiologia 249: 183-188.

Rihab, B. A., B. O. Sabrine, C. Lina, D. Imed, B. O. Hatem \& O. Ali, 2017. Cadmium effect on physiological responses of the tolerant Chlorophyta specie Picocystis sp. isolated from Tunisian wastewaters. Environmental Science and Pollution Research 24: 1803-1810.

Roelke, D. L., A. Barkoh, B. W. Brooks, J. P. Grover, K. D. Hambright, J. W. LaClaire, P. D. Moeller \& R. Patino, 2016. A chronicle of a killer alga in the west: ecology, assessment, and management of Prymnesium parvum blooms. Hydrobiologia 764: 29-50.

Roesler, C. S., C. W. Culbertson, S. M. Etheridge, R. Goericke, R. P. Kiene, L. G. Miller \& R. M. Oremland, 2002. Distribution, production, and ecophysiology of Picocystis strain ML in Mono Lake, California. Limnology and Oceanography 47: 440-452.

Rothschild, L. J. \& R. L. Mancinelli, 2001. Life in extreme environments. Nature 409(6823): 1092-1101.

Rugema, E., F. Darchambeau, H. Sarmento, M. StoynevaGärtner, M. Leitao, W. Thiery, A. Latli \& J.-P. Descy, 2019. Long-term change of phytoplankton in Lake Kivu: the rise of the greens. Freshwater Biology 64: 1940-1955.
Salmi, P. \& K. Salonen, 2016. Regular build-up of the spring phytoplankton maximum before ice-break in a boreal lake. Limnology and Oceanography 61: 240-253.

Säwström, C., P. Mumford, W. Marshall, A. Hodson \& J. Laybourn-Parry, 2002. The microbial communities and primary productivity of cryoconite holes in an Arctic glacier (Svalbard 79 N). Polar Biology 25: 591-596.

Schagerl, M. \& O. S. Odour, 2003. On the limnology of Lake Baringo (Kenya): II. Pelagic primary production and algal composition of Lake Baringo, Kenya. Hydrobiologia 506-509: 297-303.

Schagerl, M. \& S. O. Oduor, 2008. Phytoplankton community relationship to environmental variables in three Kenyan Rift Valley saline-alkaline lakes. Marine and Freshwater Research 59: 125-136.

Scheffer, M., S. H. Hosper, M. L. Meijer, B. Moss \& E. Jeppesen, 1993. Alternative equilibria in shallow lakes. Trends in Ecology and Evolution 8: 275-279.

Scheffler, W. \& J. Padisák, 2000. Stephanocostis chantaicus (Bacillariophyceae): morphology and population dynamics of a rare centric diatom growing in winter under ice in the oligotrophic Lake Stechlin, Germany. Algological Studies 133: 49-69.

Schmidt, A., F. Vasas \& I. Dobler, 1990. Adatok a Gonyostomum latum Ivanov magyarországi előfordulásáról. (Angaben über das Vorkommen von Gonyostomum latum in Ungarn). Botanikai Közlemények 77: 39-46.

Schönknecht, G., W. H. Chen, C. M. Ternes, G. Barbier, R. P. Shrestha, M. Stanke, A. Bräutigam, B. J. Baker, J. F. Banfield \& R. M. Garavito, 2013. Gene transfer from bacteria and archaea facilitated evolution of an extremophilic eukaryote. Science 339: 1207-1210.

Seckbach, J. (ed.), 2013. Enigmatic Microorganisms and Life in Extreme Environments. Springer Science \& Business Media, Berlin.

Selmeczy, G. B., A. Abonyi, L. Krienitz, P. Kasprzak, P. Casper, A. Telcs, Z. Somogyvári \& J. Padisák, 2019. Old sins have long shadows: climate change weakens efficiency of trophic coupling of phyto-and zooplankton in a deep oligomesotrophic lowland lake (Stechlin, Germany): a causality analysis. Hydrobiologia 831: 101-117.

Sommer, U., J. Padisák, C. S. Reynolds \& P. Juhász-Nagy, 1993. Hutchinson's heritage: the diversity-disturbance relationship in phytoplankton. Hyrdobiologia 249: 1-8.

Somogyi, B., L. Vörös, K. Pálffy, G. Székely, C. Bartha \& Z. G. Keresztes, 2014. Picophytoplankton predominance in hypersaline lakes (Transylvanian Basin, Romania). Extremophiles 18: 1075-1084.

Somogyi, B., K. Pálffy, K. V. Balogh \& L. Vörös, 2017. Unusual behaviour of phototrophic picoplankton in turbid waters. PLoS ONE 12: e0174316.

Souza, M. B., C. F. Barros, F. A. R. Barbosa, E. Hajnal \& J. Padisák, 2008. Role of atelomixis in replacement of phytoplankton assemblages in Dom Helvécio Lake, SouthEast Brazil. Hydrobiologia 607: 211-224.

Stewart, K. M. \& R. F. Platford, 1986. Hypersaline gradients in two Canadian High Arctic lakes. Canadian Journal of Fisheries and Aquatic Sciences 43: 1795-1803.

Stockwell, J. D., J. P. Doubek, R. Adrian, O. Anneville, C. C. Carey, L. Carvalho, L. N. De Senerpont Domis, G. Dur, M. A. Frassl, H.-P. Grossart, B. W. Ibelings, M. 
J. Lajeunesse, A. M. Lewandowska, M. E. Llames, S.-I. S. Matzuzaki, E. R. Nodine, P. Nõges, V. P. Patil, F. Pomati, K. Rinke, L. G. Rudstam, J. A. Rusak, N. Salmaso, C. T. Seltmann, D. Straile, S. J. Thackeray, W. Thiery, P. Urrutia-Cordero, P. Venail, P. Verburg, R. I. Woolway, T. Zohary, M. R. Andersen, R. Bhattacharya, J. Hejzlar, N. Janatian, A. T. N. K. Kpodonu, T. J. Williamson \& H. L. Wilson, 2020. Storm impacts on phytoplankton community dynamics in lakes. Global Change Biology 26: 2756-2787.

Tarazona Delgado, R., H. M. Terreros, M. M. Astocóndor \& E. M. Huatuco, 2017. Picocystis salinarum (Prasinophyceae, Chlorophyta) en las Salinas de Chilca, Lima, primer registro para el Perú. Arnaldoa 24: 557-566.

Tavera, R. \& V. Martínez-Almeida, 2005. Atelomixis as a possible driving force in the phytoplankton composition of Zirahuén, a warm-monomictic tropical lake. Hydrobiologia 533: 199-208.

Tittel, J., V. Bissinger, U. Gaedke \& N. Kamjunke, 2005. Inorganic carbon limitation and mixotrophic growth in from an acidic mining lake. Protist 156: 63-75.

Ulrich, S. \& K. Röske, 2018. Autumnella lusatica gen. nov. and sp. nov. (Chlorophyta, Trebouxiophyceae), a new phytoplankton species in acidic lignite pit lakes. Phycologia 57: 251-261.

Unrein, F. \& A. Vinocur, 1999. Phytoplankton structure and dynamics in a turbid Antarctic lake (Potter Peninsula, King George Island). Polar Biology 22: 93-101.

Üveges, V., K. Tapolczai, L. Krienitz \& J. Padisák, 2012. Photosynthetic characteristics and physiological plasticity of an Aphanizomenon flos-aquae (Cyanobacteria, Nostocaceae) winter bloom in a deep oligo-mesotrophic lake (Lake Stechlin, Germany). Hydrobiologia 698: 263-272.

Vadlamani, A., S. Viamajala, B. Pendyala \& S. Varanasi, 2017. Cultivation of microalgae at extreme alkaline $\mathrm{pH}$ conditions: a novel approach for biofuel production. ACS Sustainable Chemistry \& Engineering 5: 7284-7294.

Van Donk, E., B. A. Faafeng, H. J. de Lange \& D. O. Hessen, 2001. Differential sensitivity to natural ultraviolet radiation among phytoplankton species in Arctic lakes (Spitsbergen, Norway). Plant Ecology 154: 247-259.

Vareschi, E., 1982. The ecology of Lake Nakuru (Kenya) III. Abiotic factors and primary production. Oecologia 55: 81-101.

Vehmaa, A. \& K. Salonen, 2009. Development of phytoplankton in Lake Pääjärvi (Finland) during under-ice convective mixing period. Aquatic Ecology 43: 693-705.

Vincent, W. F. \& C. L. Vincent, 1982. Factors controlling phytoplankton production in Lake Vanda (77 S). Canadian Journal of Fisheries and Aquatic Sciences 39: 1602-1609.

Vízkelety, É., 1981. Adatok a Hévízi-tó algáinak ismeretéhez. (Angaben zur Algenkenntnis des Sees von Hévíz). A Veszprém Megyei Múzeumok Közleményei 16: 33-39.

Vonshak, A., N. Kancharaksa, B. Bunnag \& M. Tanticharoen, 1996. Role of light and photosynthesis on the acclimation process of the cyanobacterium Spirulina platensis to salinity stress. Journal of Applied Phycology 8: 119-124.

Webb, D. J., R. D. Robarts \& E. E. Prepas, 1997. Influence of extended water column mixing during the first 2 years of hypolimnetic oxygenation on the phytoplankton community of Amisk Lake, Alberta. Canadian Journal of Fisheries and Aquatic Sciences 54: 2133-2145.

Webb, W. L., M. Newton \& D. Starr, 1974. Carbon dioxide exchange of Alnus rubra: a mathematical model. Oecologia 17: 281-291.

Weiss, M. \& U. Pick, 1996. Primary structure and effect of $\mathrm{pH}$ on the expression of the plasma membrane $\mathrm{H}^{+}$-ATPase from Dunaliella acidophila and Dunaliella salina. Plant Physiology 112: 1693-1702.

Weyhenmeyer, G. A., E. Willén \& L. Sonesten, 2004. Effects of an extreme precipitation event on water chemistry and phytoplankton in the Swedish Lake Mälaren. Boreal Environment Research 9: 409-420.

Weithoff, G., M. Moser, N. Kamjunke, U. Gaedke \& T. Weisse, 2010. Lake morphometry and wind exposure may shape the plankton community structure in acidic mining lakes. Limnologica-Ecology and Management of Inland Waters 40: 161-166.

Williams, W. D., 1986. Conductivity and salinity of Australian salt lakes. Marine and Freshwater Research 37: 177-182.

Wollmann, K., R. Deneke, B. Nixdorf \& G. Packroff, 2000. Dynamics of planktonic food webs in three mining lakes across a pH gradient ( $\mathrm{pH} 2-4)$. Hydrobiologia 433: 3-14.

Wu, J. T. \& L. C. Kow, 2010. Alteration of phytoplankton assemblages caused by changes in water hardness in Feitsui Reservoir, Taiwan. Botanical Studies 51: 521-529.

Wurtsbaugh, W.A. \& A. M. Marcarelli, 2004. Phytoplankton and zooplankton in Farmington Bay and the Great Salt Lake, Utah (2003). Report to the Central Davis Sewer Improvement District, Kaysville, UT. http://www.cdsewer. org/GSLRes/2004_Phytoplankton_and_Zooplankton_ Report_2003_Data_-_USU.pdf. Accessed on 13 January, 2020.

Yan, N. D. \& P. Stokes, 1978. Phytoplankton of an acidic lake, and its responses to experimental alterations of $\mathrm{pH}$. Environmental Conservation 5: 93-100.

Zinabu, G. M., L. J. Chapman \& C. A. Chapman, 2002. Conductivity as a predictor of a total cations and salinity in Ethiopian lakes and rivers: revisiting earlier models. Limnologica 32: 21-26.

Znachor, P., E. Zapomělová, K. Řeháková, J. Nedoma \& K. Šimek, 2008. The effect of extreme rainfall on summer succession and vertical distribution of phytoplankton in a lacustrine part of a eutrophic reservoir. Aquatic Sciences 70: $77-86$.

Publisher's Note Springer Nature remains neutral with regard to jurisdictional claims in published maps and institutional affiliations. 